REVIEW

Published July 13, 2018

\title{
Sex Differences in HIV Infection: Mystique Versus Machismo
}

\section{AUTHOR}

Eileen P. Scully ${ }^{1}$

\section{AFFILIATED INSTITUTION}

${ }^{1}$ Department of Medicine, Division of Infectious Diseases, Johns Hopkins University School of Medicine

\section{CORRESPONDING AUTHOR}

Eileen P. Scully

855 N. Wolfe Street

Rangos Building, Room 530B,

Baltimore, MD 21205

escully1@jhmi.edu

\section{SUGGESTED CITATION}

Scully EP. Mystique versus Machismo: Sex Differences in HIV Infection. Pathogens and Immunity. 2018;3(1):82-113. doi: 10.20411/pai.v3i1.238

\section{ABSTRACT}

Biological sex is a determinant of both susceptibility to and pathogenesis of multiple infections, including HIV. These differences have effects on the spectrum of HIV disease from acquisition to eradication, with diverse mechanisms including distinct chromosomal complements, variation in microbiota composition, hormonal effects on transcriptional profiles, and expression of different immunoregulatory elements. With a comparative biology approach, these sex differences can be used to highlight protective and detrimental immune activation pathways, to identify strategies for effective prevention, treatment, and curative interventions.

\section{KEYWORDS}

HIV; gender; sexually transmitted diseases; immune response 


\section{INTRODUCTION}

Social, behavioral, and biological differences between men and women have a clear influence on the natural history of disease and the response to therapeutic interventions. The fact that men and women are different is simultaneously treated as manifest and inconsequential in many scientific studies; traditionally, medical science has approached sex as a source of variation requiring controlled analysis, but there has been limited investigation into the mechanisms of these differences. Within the spectrum of HIV disease, sex differences have a greater significance, and these differences are critical to understand for the design of clinical interventions and trials. Furthermore, the distinctions between men and women offer a unique point of leverage for defining disease pathways that can be modulated for the goals of vaccine-induced protection, attenuated pathogenesis, or cure. This review outlines the data's delineating sex-based differences in acquisition, disease progression, and potential for cure. Potential mechanisms for these differences are highlighted, linking HIV to other infections and vaccine responses and emphasizing the areas in need of further research. For each of these sections, the known differences are placed in the context of their implications for current clinical challenges for HIV prevention, management of the complications of disease, and efforts at eradication.

\section{ACQUISITION}

The emergence of HIV in men who have sex with men (MSM) in the United States [1] is in contrast to the modern, mature HIV epidemic where a significant burden of infection worldwide is borne by women; 59\% of infections in Sub-Saharan Africa and 51\% of total infections worldwide are in women and girls [2] . Although the epidemic is generalized, important sex distinctions with respect to disease acquisition remain. Behavioral and socioeconomic factors drive a substantial proportion of the difference in acquisition between men and women. This was highlighted by early studies suggesting lower efficacy of pharmacologic pre-exposure prophylaxis in women, a difference ultimately attributed to very low adherence in some studies of women [3-5]. However, biological determinants of host susceptibility are modulated by sex, substantially contributing to risk differentials [6]. Sex-based variation offers critical insights into pathways that may be relevant to prevention efforts with either pharmacologic strategies or vaccination.

\section{Anatomy, microbiome, and sexually transmitted diseases}

Male to female sexual transmission is more efficient; penile-vaginal sex carries an approximately 2 -fold higher risk of HIV acquisition for the receptive partner versus the insertive partner in a serodiscordant encounter [7] . The portal of entry for sexual transmission is a primary difference, with significant differences in epithelial barrier function and immune cell complement between the penile and rectal mucosal surfaces and the female genital tract. In the female genital tract enhanced susceptibility is associated with local inflammation [ $[\underline{8}, \underline{9}]$; data suggest that specific patterns of cytokines and chemokines associate with a local influx of cells susceptible to HIV infection and with changes in the expression of factors promoting mucosal barrier maintenance [10]. This may facilitate transmission of less fit viruses [11] and increase the likelihood of infection. Sexually transmitted infections (STIs) are one driver of inflammation in the genital tract [12, 13] and have been linked to enhanced transmission of HIV [14-16] in both men and women. Of note, women have an enhanced risk of HIV-infection associated with laboratory diagnosed STIs, even in the absence of clinically symptomatic infection[17]. 
Growing evidence suggests that another significant contributor to inflammation in the female genital tract is the local microbiome [18-20]. In addition to effects on inflammation and STI coinfection, microbiome composition has been linked to alterations in genital tract wound healing [21], another pathway of susceptibility. Recent data also directly implicate microbial metabolism with altered drug levels and reduced efficacy seen with specific microbiome patterns [22]. Taken together, data indicate that the balance of local bacteria, including commensals and pathogens, and resulting inflammation and local tissue effects can profoundly impact the risk of HIV acquisition; these factors have clear anatomical differences in men and women with implications for prevention strategies. In the specific case of tenofovir, the local metabolism by microbial communities described above will reduce efficacy in women [22], whereas data from studies in men suggest that tenofovir gel exposure is associated with downregulation of RNA coding for inflammatory regulators in rectal biopsies, potentially increasing protective effects [23].

\section{Sex Hormones}

The risk in the female genital tract is then further modulated by the exposure to sex hormones. Animal studies have previously identified a link between SIV acquisition and high progesterone levels either due to menstrual cycle variation [24-26] or to exogenous administration of progestins, modeling contraceptives [ $\underline{27}, \underline{28}]$. In humans, the data are difficult to parse. Progestin-related thinning of vaginal mucosal surfaces in non-human primates (NHPs) is well described, [27-29] but the data in women have shown little or no change in vaginal epithelial thickness in association with depot medroxyprogesterone (DMPA) use [30-34]. Despite this clear difference from the primate model, the preponderance of data does support an increase in HIV acquisition risk in association with DMPA use, with meta-analysis estimates of a hazard ratio in the range of 1.4; no association with other contraceptives has been consistently observed [35-37]. Recent data from a prospective cohort have suggested that there are higher numbers of HIV-susceptible target cells in the cervix in the setting of higher progesterone (based on menstrual cycle or DMPA administration) [38], indicating one potential mechanism for increased acquisition. The effects of hormonal contraception also intersect with risks associated with local microbiota as recent data have also shown that vaginal inflammatory profiles are modulated by both hormonal contraception and local microbiota and concurrent sexually transmitted infections [39].

\section{Sex differences in the immune response}

Finally, the efficacy of vaccination to block acquisition may also vary between the sexes. Genetic and hormonal factors combine to produce sex-specific variations in the immune responses to vaccines as measured by both efficacy and adverse effects [40]. Examples include the increased risk of women of childbearing age to the rare complication of fatal visceroptropic disease following receipt of the yellow fever vaccine $[\underline{41}, \underline{42}]$ and the HSV glycoprotein vaccine which had protective efficacy in women but not in men [43]. Sex differences in HIV vaccine responses are still a subject of exploration. In the only vaccine trial with a protective effect (RV144), the efficacy was $25.8 \%$ in men $(n=4875)$ and $38.6 \%$ in women $(n=3085)$ although this difference was not statistically significant [44]. Potential mechanisms for differences in vaccine efficacy and safety include immune subset variations and differences in pathogen sensing and inflammatory pathway activation. A secondary analysis of RV144 reported sex differences in circulating levels of myeloid and plasmacytoid dendritic cells (pDCs) and a subset of natural killer (NK) cells although these values were not specifically related to protective efficacy [45]. Transcriptional signatures induced 
by the yellow fever vaccine identified gene programs critical to vaccine-induced protection [46] and a sex-stratified analysis of this data identified distinct gene pathways activated in men versus women [47]. These variations suggest that adjuvant strategies, antigen dose, or site of delivery could all potentially be optimized for more efficacious vaccines. Given the challenges in designing an effective vaccine for prevention of HIV, exploiting immunologic differences between men and women may illuminate pathways critical to generating protective immunity.

From a genetic perspective, the sex chromosomes carry immunoregulatory genes. The X chromosome carries TLR7 and TLR8 (both encoding pathogen sensors, the former tightly linked to type 1 interferon production) and FOXP3 (a transcription factor critical for regulatory $\mathrm{T}$ cell development) and a high density of regulatory micro RNA sequences [48-50]. Specific Y chromosome polymorphisms have also been associated with infection susceptibility suggesting immune activity $[\underline{51}, \underline{52}]$. While there is not a strict gene dosage effect (due to $\mathrm{X}$ inactivation), having two $\mathrm{X}$ chromosomes even in the setting of phenotypic male sex (ie Klinefelter's syndrome, XXY) has immunologic consequences; it is associated with increased prevalence of the female predominant autoimmune disease systemic lupus erythematosus (SLE) [53]. Recent work has demonstrated the variability of $\mathrm{X}$ chromosome inactivation and consequences for disease pathogenesis [54-56]; biallelic expression of TLR7 has recently been demonstrated and linked to the development of autoimmune disease [57]. Taken together, the evidence suggests the sex chromosome complement has important consequences for immune function and may drive different inflammatory pathways.

Superimposed on the genetic differences are the effects of sex hormones, including estrogen, progesterone, and androgens, all modulators of immune function. With the caveat that in vitro modeling of hormonal milieu is difficult, there is evidence for immune suppressive effects of progesterone on multiple cell types and for concentration-dependent proinflammatory effects of estrogen on specific cells [ $\underline{51}$ ]. Furthermore, estrogen, through upregulation of interferon regulatory factor 5 (IRF5) has been reported to enhance type 1 interferon production in response to TLR7 stimulation [58]. Importantly, multiple diverse genes have estrogen regulatory elements in their promoter regions, suggesting that they may be directly controlled by sex hormone exposure. The effects of sex hormones may directly modulate both vaccine efficacy and the natural development of immunity in HIV infection.

\section{Implications}

Sex differences in acquisition offer insights critical to the development of effective prevention efforts. In addition to important behavioral determinants that differ for men and women, sex confers distinct biological risks. This includes factors that enhance transmission through changes in barrier maintenance, target cell availability, local inflammation, and prophylactic drug concentrations as well as variations in vaccine response. There is an urgent need to fully define the role of exogenous hormones given to women as contraception; the critical role of effective contraception is clear, but identifying the methods most compatible with prevention of HIV transmission should share priority. Sex differences in vaccine responses should also be clearly defined as they may point to optimal adjuvant strategies that will be effective in both sexes. 


\section{IMMUNE RESPONSE AND PATHOGENESIS}

\section{Viral load}

Once HIV infection has been established sex differences persist and in some cases amplify. Early in the HIV epidemic, work that first demonstrated the link between measures of viral activity and disease progression also highlighted a difference in baseline viral loads between men and women [59]. Several subsequent studies identified similar differences in HIV viral load [60-65], although other studies did not recapitulate this finding $[\underline{66}, \underline{67}]$. Taken together, the preponderance of the data indicates that women have lower levels of HIV RNA, although there is some convergence in this measure over time and with disease progression $[\underline{68}, \underline{69}]$. This subtle difference in viral load raised important clinical questions: rates of disease progression did not differ between men and women, suggesting that the viral load thresholds did not adequately identify women at risk for progressive disease. Antiretroviral therapy guidelines initially incorporated viral load measures, leading to significant differences in treatment eligibility between men and women with disease progression: in one study $74 \%$ of male versus $37 \%$ of female progressors were eligible for therapy in the first year after seroconversion [64]. Setting aside the clinical questions regarding treatment initiation, the viral load gap between men and women also opened significant questions about disease pathogenesis and the determinants of an effective immune response.

The viral load of an individual infected with HIV is determined by a combination of the characteristics of the infecting virus itself and the host immune response, with the most extreme examples seen in patients who spontaneously suppress or control viremia (reviewed in [70-74]). Women are overrepresented in some cohorts of immune controllers of HIV $[\underline{75}, \underline{76}]$ raising questions about whether sex differences in immune responses track with features linked to spontaneous viral suppression. Given the heterogeneous characteristics of HIV controllers, separating the sex-based components may amplify subtle differences that confer immunologic advantages. A sex-based difference in HIV control is consistent with an extensive body of literature documenting distinctions between the sexes in acquisition and progression of viral infections and in the protective efficacy of and adverse responses to vaccinations $[\underline{51}, \underline{52}, \underline{77}, \underline{78}]$. However, there is little evidence to define a mechanism for the difference in HIV infection.

From the standpoint of protective genetic factors, it is notable that many genome association studies, including the International H.I.V. controllers study [79], analyze only the autosomal chromosomes. Given the multiple X-encoded miRNAs and immune regulatory genes, this analysis may have omitted factors with relevance to viral control. As there is evidence that sex-based viral load distinctions are also seen in children prior to puberty [요] , the role of chromosomal differences merits consideration. Focused exploration of sex-chromosome-linked genetic determinants in HIV control is increasingly feasible as new analytic methods are developed for including the $\mathrm{X}$ chromosome in genetic association studies $[\underline{81}, \underline{82}]$. In addition, the role of steroid hormones in the direct modulation of HIV transcription will be discussed below.

Overall, HIV viral loads tend to be lower in women during early infection, and there is an enrichment of women among spontaneous and post-treatment controllers. This suggests that either hormonal modulation of virus or immune response, or direct sex-linked genetic variation that alters the immune response is contributing to virologic control. Isolating sex as a variable may highlight the protective pathways. 


\section{HIV specific T cell responses}

There are limited studies comparing HIV-specific immunity in men and women, and many cohort studies have limited participation of women [83] leaving many questions about how the sex differences in immune response contribute to viral control. One study specifically quantified $\mathrm{CD}^{+} \mathrm{T}$ cell responses in both sexes at two time points after seroconversion, demonstrating that these responses were correlated with $\mathrm{CD}^{+} \mathrm{T}$ cell counts in women but not in men [84]. Interestingly, the $\mathrm{CD}^{+} \mathrm{T}$ cell responses did not differ in magnitude by sex, leading the authors to suggest that the differences observed in viral load between men and women on the population level may not be directly linked to cytotoxic $\mathrm{T}$ cell function [84]. Despite the lack of augmented T cell responses in this single study, in non-HIV studies, there was evidence of an amplified T cell activation and proliferation in mucosal $\mathrm{T}$ cells from women [85]. Likewise, gene expression analysis in HIV negative populations showed higher induction of inflammatory pathways in cytotoxic T cells from women after in vitro re-stimulation; estrogen receptor elements were identified in the promoter regions of many of these differentially expressed genes [6]. Further work is necessary to parse whether there are sex differences in T cell responses relevant to control of plasma viral load.

T cell activation is part of a profile of chronic immune activation associated with HIV viremia and disease progression. There is an inverse relationship between survival and $\mathrm{T}$ cell activation in patients with advanced immunodeficiency [ㄱ] , and $\mathrm{CD}^{+} \mathrm{T}$ cell activation in early disease is a strong predictor of immunologic progression [요. These findings focused attention on the host immune response as a critical determinant of the pathogenesis of AIDS, irrespective of levels of plasma viral load. Again, biological sex is an important modifier; women have a higher level of $\mathrm{CD}^{+} \mathrm{T}$ cell activation when controlled for viral load [이 ] suggesting an inflammatory mechanism for the relatively more rapid disease progression seen in women at lower viral loads. The drivers of heightened $\mathrm{T}$ cell activation are likely to include sex differential innate immune responses including production of IFN- $\alpha$ as detailed below.

\section{Innate immune responses}

Innate immune cells prime and promote adaptive responses, and they also mediate direct host protection through recognition and elimination of infected targets. pDCs are the dominant source of type 1 interferon, and pDCs from women produce higher levels of IFN- $\alpha$ when stimulated with HIV-derived Toll-like receptor ligands (TLRs) [일, one potential driver of CD8 ${ }^{+} \mathrm{T}$ cell activation. As the X chromosome encodes TLRs that directly sense HIV (including TLR7), the sex chromosome complement likely contributes to the amplified production of interferon. In addition, hormones, in particular estrogen, influence $\mathrm{pDC}$ IFN-a production in part through direct effects on the expression of interferon regulatory factor 5 (IRF5) [포, $\underline{90}, \underline{91}$. Prior work has also suggested a role for progesterone in the regulation of $\mathrm{pDC}$ function. In vitro studies showed a potent inhibitory effect of direct coculture with hormone[92] in contrast to an enhanced IFN- $\alpha$ response from pDCs sampled from high progesterone individuals [우]. As these studies highlight, hormone exposure needs to be considered as a net effect of multiple inputs, obligating careful interpretation of in vivo studies.

Genetic associations and in vitro studies combine to demonstrate a role in HIV pathogenesis for another innate antiviral effector, the natural killer (NK) cell (reviewed in [ $\underline{93}, 94]$ ). NK cell function is highly sex-specific with respect to reproduction, where there is clear evidence of evolutionary interactions between NK-cell receptors and HLA ligands [95], and associations with preg- 
nancy loss and intrauterine growth restriction (reviewed in [ $[\underline{96}, 97]$ ). There is less data to define the role of sex in modulating the function of NK cells at other sites. Age, sex, and menstrual cycle effects on peripheral NK-cell distribution and function have been reported [98, 99], but it is difficult to interpret the relevance of these variations to disease $[\underline{100}, \underline{101}]$. More focused research is warranted to determine whether sex is associated with relevant differences in NK-cell activity.

Monocytes are another innate cell population critically important to HIV pathogenesis. Monocyte activation has been linked to soluble markers of inflammation that are associated with morbidity and mortality [102] and have been mechanistically linked to coagulation abnormalities that may contribute to cardiovascular events in HIV-infected individuals [103, 104]. Of note, lipid metabolism pathways are linked to monocyte and innate cellular activation in the general population (reviewed in [105]), and lipids are modulated by sex hormones [106]. Although there are limited studies in patients with HIV, in uninfected populations, lower percentages of $\mathrm{CD} 14^{+} \mathrm{CD} 16^{++}$ monocytes have been reported in healthy women [107], and increased monocyte activation has been reported in women with systemic lupus erythematosus [108]. Lipid metabolism is linked to innate cellular activation (reviewed in [105]) and the sex hormone effects on lipids [106] are a potential mechanism for differences between men and women. Soluble markers of innate immune activation are predictive of HIV disease outcomes in cohort studies, but it is not clear if their performance is accurate in women. The magnitude of changes in biomarkers after initiation of ART has been reported to differ between men and women, but these studies are difficult to interpret. In many cases, there are different levels of pretreatment elevation, and a smaller net change in women may lead to comparable plasma levels. In that context it is difficult to determine whether there is a relevant sex difference in treatment response [109-111].

\section{Humoral immunity}

Sex differences extend to antibody formation, with more robust induction of antibody responses to vaccines, higher rates of autoreactive antibodies, and higher baseline levels of some immunoglobulin subclasses in women (reviewed in [112]). There is evidence for a direct effect of sex hormones, most notably in the proposed role of estrogen in promoting somatic hypermutation and decreasing the stringency of selection against autoreactivity [112]. In contrast, testosterone has been linked to a profile of lipid metabolism that is associated with lower responses to influenza vaccination [113]. Sex differences have been described in many vaccine responses, and the range of ages studied (including prepubertal subjects) suggests that sex hormones are not solely responsible for these differences [40]. In the specific case of HIV, sex differences in the frequency of broadly neutralizing antibody responses (bNabs) to HIV have not been apparent [114], although neutralizing responses are tied to viral load [115], which does have sex specific determinants, as discussed previously.

While a potent pathway for prevention of new infection, neutralization is not the only protective function of antibodies. The modest efficacy seen in the RV144 HIV vaccine trial was associated with non-neutralizing antibody titers [116] . In addition, the antibodies generated by RV144 had more polyfunctional non-neutralizing Fc effector domains when compared to the non-protective VAX003 vaccine trial [117]. Antibody subclass and Fc glycosylation patterns are important determinants of the non-neutralizing functional profiles of antibodies [118]. Ongoing research is exploring the pathways for tuning glycosylation patterns to optimize these antibody functions [119]. Of note, glycan modifications are influenced by age and sex, and levels of estrogen have 
been linked to a predominance of specific glycoforms [120]. A separate link between the sex hormone milieu and antibody glycan modifications is suggested by the pregnancy-associated changes in rheumatoid arthritis disease activity and the associated patterns of circulating antibody glycosylation $[121,122]$. In the tissues of the female reproductive tract, hormones associate with changes in glycosylation machinery [123]. Recent work has directly linked estrogen levels with and without pharmacologic modulation to patterns of glycosylation in bulk IgG [124]; further work is necessary to assess the effects in antigen-specific antibodies. A more detailed understanding of the role of sex and sex hormones in this process may lead to strategies for natural optimization of the antibody glycoprofile in both women and men.

\section{Microbiome}

Inflammation and disease pathogenesis in HIV infection have also been linked to microbial translocation events [125] prompting efforts to shape the gut-associated microbiome to optimize immune parameters [126-128]. Differences in the microbiota of the reproductive tracts with consequences for the efficacy of PrEP have been well described, however, there are also sex differences in the gut microbiota between men and women. Sex hormones favor the predominance of specific microbial communities, and in animal studies they have been linked to the sex-specific susceptibility to autoimmune diseases $[\underline{129}, \underline{130}]$. Human studies have confirmed the association of sex with specific microbiome characteristics [131-133]. Further studies are needed to define the influence of sex on gut microbial communities and the consequences of a particular microbiome composition for microbial translocation and inflammation.

\section{Implications}

For both the exceptional case of immune control and the more typical phenotype of disease progression, sex differences in HIV infection present several opportunities to further delineate the mechanisms of HIV pathogenesis. A heightened inflammatory response may offer a selective advantage for establishing a state of viral control, but in the more typical case of disease progression, this will confer a risk for amplified pathology and disease progression at lower viral loads. Furthermore, these differences may contribute to inflammatory comorbidities in HIV including cardiovascular disease. Analyses of women with known hormonal status (premenopausal and postmenopausal, exposure to exogenous hormones) will help to define the contribution of hormones, a pathway that can be pharmacologically modified. Likewise, differences in the immune response to infection may also lead to efforts at successful vaccine design.

\section{HIV CURE}

Embedded within the discussion of treated HIV disease is the question of whether sex differences will be relevant to strategies for cure. Again, the role of sex is not fully defined, but the biological distinctions between men and women may offer points of leverage. A successful intervention will either definitively eradicate the latent proviral HIV reservoir (eg, through the "shock and kill" approach) or will establish a state of durable immune control or transcriptional silencing to prevent resurgence of the virus after withdrawal of ART (ie, a "functional cure") (reviewed in [134-136]). While the case of the Berlin patient $[137,138]$ stands as a point of optimism for the potential to achieve a durable cure of HIV, subsequent cases have demonstrated the challenges of achieving viral eradication [139-142]. The recently described post-treatment controller (PTC) cohort of individuals with durable suppression of viral replication after withdrawal of ART offers a natural 
model of the goal of functional cure [143]. Of note, as with immune controllers, an association between female sex and PTC status has been reported, albeit based on small numbers [144]. The field of HIV cure research has advanced rapidly in both the basic discovery phase and through clinical trials, but women are underrepresented in these studies [145]. Their limited representation may lead to missed opportunities to identify sources of biological variability that may have relevance. Importantly, many of the curative interventions proposed target the host immune system and not the virus; this means that there is a greater chance of sex differences in responses, which should be carefully considered while therapies are developed and tested.

To frame the discussion of potential sex differences, we will divide cure research into a few domains. Areas of active investigation include 1) defining the size and location of the reservoir, 2) identifying pathways to latency reversal or more permanent silencing of transcription, and 3) mobilizing the immune response to clear infected cells. We will focus the discussion on the first 2 points here, as sex differences in the priming and direction of immune responses via vaccination and following infection were discussed previously.

\section{Defining the reservoir}

Defining the reservoir will identify the targets and delineate the threshold required to eliminate or silence HIV [146]. Several measures have been proposed, each with their caveats. Measurement of the proviral DNA reservoir of HIV has been shown to be predictive of the time to rebound after interruption of therapy in a clinical trial [147]. The HIV DNA reservoir prior to therapy is correlated with plasma viral load and had clinical prognostic value for untreated disease progression [147, 148]. This DNA reservoir is established early during infection and is relatively stable, although it can be significantly reduced by the initiation of ART [149]. The measure also has important limitations, as ex vivo studies have demonstrated that a significant proportion of proviruses measured in HIV DNA assays are defective at the sequence level [150], even when measured during acute infection [151], and are not a measure of the replication competent reservoir. Of note, viral RNA species from defective sequences [152] may also contribute to immune activation and pathogenesis, suggesting an importance of the DNA reservoir irrespective of replication competence. However, it is a challenge that there is limited correlation between measures of HIV DNA, RNA, and outgrowth of viruses in vitro [153], and the factors governing the establishment of the DNA reservoir are incompletely defined. Two cross-sectional studies with women participants have suggested that female sex is associated with a lower HIV DNA reservoir in peripheral blood mononuclear cells (PBMCs) $[154,155]$. These studies were not specifically designed to test sex as a variable, and approximately $30 \%$ of the participants were women. In contrast, data from a prospectively recruited cohort of matched men and women showed no significant differences in HIV DNA reservoir measures in $\mathrm{CD}^{+} \mathrm{T}$ - cells [156].

Residual HIV expression measured by HIV RNA expression offers a different index of virus activity. Measurements of both cell-associated unspliced (CA-US) and multiply-spliced (CA-MS) RNA transcripts have been used in a variety of studies to quantify HIV expression, although the precise significance of these types of transcripts is a topic of ongoing discussion (reviewed in [157]). The level of CA-RNA was reported to associate with time to rebound in one cohort undergoing an analytic treatment interruption [158], suggesting that this measure may have utility in assessing the potential for cure. Women have lower levels of CA-MS RNA transcripts and lower levels of plasma HIV RNA as measured by a single copy assay [156]. These results suggest that in this particu- 
lar cohort in which HIV DNA levels were comparable, there may be important differences in HIV RNA production and residual viremia. Measurement of in vitro production of replication-competent virus, which has been proposed as the measure most tied to risk of rebound viremia, has not been systematically compared between men and women.

\section{HIV RNA expression and latency reversal}

Sex steroids may contribute to differences in CA-RNA levels through transcriptional control. The estrogen receptor associates with the HIV-1 long terminal repeat in combination with other transcription factors, and $17 \beta$-estradiol has an inhibitory effect on HIV replication $[159$, 160]. Another study using combinations of estrogen and progesterone suggested that high levels of hormone exposure inhibited and lower levels enhanced HIV transcriptional activity [161], although this study did not isolate transcriptional effects and bystander cytokine secretion may have also played a role. Using a small hairpin RNA knockdown screen, Karn and colleagues identified the estrogen receptor as a major regulator of HIV latency reversal in cell line and primary cell models; latency reversal with a variety of activating stimulants was more efficient when estrogen was blocked [162]. This observation was further validated with ex vivo reactivation of primary human samples. In these studies, exposure to estrogen blunted the induction of HIV RNA production after stimulation of the $\mathrm{T}$ cell receptor or exposure to histone deacteylase inhibitors [162]. Notably, the repressive effect of estrogen was most pronounced in cells taken from women, ex vivo stimulation of cells from men also showed a blunting of HIV expression by estrogen, but with a smaller effect size [162]. Taken together, the data suggest that HIV transcription is directly affected by sex steroids, offering a novel pathway that can be modulated to enhance efforts at reactivation.

The precise determinants of latency maintenance and the ideal pathway for selective activation of HIV transcription remain open questions (reviewed in [163]). Current efforts at latency reversal have included a significant focus on the histone deacetylase inhibitor class of chromatin remodeling agents (reviewed in [164]). Distinct methylation and transcriptional profiles of immune cells from men and women underline the epigenetic controls of sex differences [165]; these differences may have implications for the efficacy of chromatin-remodeling agents in HIV latency reversal. Other stages between a latent provirus and production of a replication-competent viral particle such as post-transcriptional and post-translational modifications and trafficking may also be targets for functional cure strategies. To date, there are no specific data to suggest sex differences at these stages in the viral life cycle.

\section{Immunomodulatory therapies}

Other agents in preclinical or early clinical trials for HIV cure include immunomodulators including checkpoint inhibitors such as anti-PD1. Sex has recently been identified as a predictor of response to anti-PD1 therapy in the setting of cancer [166]. It is not known whether these differences reflect sex effects on the therapy or on the tumor, but given the differences in immune phenotypes between men and women, responses to checkpoint inhibitor therapy in women in all settings should be carefully monitored. The TLR7 agonists are another class of agents under evaluation for latency reversal; as detailed previously, TLR7 is encoded on the X chromosome and both gene dosage [57] and hormonal effects [58] lead to sex specificity in function. Women may have a higher likelihood of both adverse effects and positive responses to this type of therapy, and sex-stratified analyses should be explored. 
Threading through this discussion is the subtext that women must be included in clinical trials in order to clearly assess sex-specific effects. A challenge to those efforts is the potential for reproductive toxicity of some of the therapies in clinical trials. Policy guidelines from the NIH on the inclusion of women in research [167] and the American College of Gynecology and Obstetrics (ACOG) on the inclusion of pregnant women [168] offer guidance on the inclusion of this more "scientifically complex" population. These factors must be considered together with the specific risks and ethical considerations in HIV-cure research along with ongoing engagement of the community living with HIV. Efforts should be made to include women in trials relevant to cure and to evaluate the efficacy of these agents in a sex-specific manner whenever feasible.

\section{Implications}

Sex differences in reservoir size, location (anatomic and cellular compartments), residual activity, integrity (ie, frequency of defective sequences), and inducibility are all possible based on the known biological differences between men and women. This represents both a challenge and an opportunity. The challenge is to include women in clinical trials while accounting for the inconvenient variance associated with hormone fluctuations, reproductive risks associated with some latency reversal agents, and the difficulty enrolling women in clinical trials. The opportunity lies in the fact that some of these biological differences will point to important mechanistic pathways that determine reservoir size and replication competence. These pathways may include direct sex hormone activity or immune factors such as the type 1 interferons.

Initial findings regarding the effect of estrogen on latency reversal have provided the basis for development of a clinical trial to test the potential for synergistic reactivation of HIV latency with estrogen blockade combined with transcriptional activators [169]. This is only the first example of how a comparative biology approach may highlight novel therapeutic pathways relevant to HIV cure.

\section{CONCLUSIONS}

Women bear a substantial share of the burden of HIV infection worldwide and remain underrepresented in clinical studies [ $\underline{83}]$ and specifically in trials relevant to cure [145]. At every stage of infection from acquisition, treatment and pathogenesis, and cure, there are sex differences in the response to HIV (Table 1). Disentangling the effects of hormone exposure from genetic determinants is 1 strategy for identifying therapeutic targets. Enrolling women who are premenopausal or postmenopausal, and studying the effects of hormones in transgender individuals may help us isolate the contribution of hormone exposure. Studies with low or unbalanced representation of women may inappropriately attribute a sex-driven difference in inflammatory or virologic characteristics to an intervention such as vaccination or a cure strategy. When enrollment of women is limited, aggregation of data from multiple sources may allow more balanced assessment of sex-specific risks. There is a need for sex-stratified analyses, proportional inclusion of women, and clinical trials to investigate biological pathways that may differ between women and men. This research would offer the promise of not only uncovering pathways relevant to women, but also of clarifying the precise regulatory pathways that may reveal interventions relevant to both men and women. 
Table 1

\begin{tabular}{|c|c|c|}
\hline Feature of HIV & Sex difference & Postulated mechanisms \\
\hline \multirow{3}{*}{ Acquisition } & $\begin{array}{l}\text { Enhanced risk of sexual trans- } \\
\text { mission to women }\end{array}$ & $\begin{array}{l}\text {-anatomic differences in mucosal surfaces } \\
\text {-hormonal modulation of target cells at } \\
\text { mucosal sites } \\
\text {-local inflammation in response to sexually } \\
\text { transmitted diseases increasing target cells }\end{array}$ \\
\hline & $\begin{array}{l}\text { Inconsistent efficacy of PrEP in } \\
\text { women }\end{array}$ & $\begin{array}{l}\text {-sociobehavioral determinants of adherence } \\
\text {-microbiome-mediated reduction of local } \\
\text { tenofovir concentrations in the female geni- } \\
\text { tal tract }\end{array}$ \\
\hline & Vaccine effectiveness & $\begin{array}{l}\text {-X chromosome genes and regulatory ele- } \\
\text { ments that affect the immune response to } \\
\text { vaccines. }\end{array}$ \\
\hline \multirow{3}{*}{ Pathogenesis } & $\begin{array}{l}\text { Lower setpoint viral loads in } \\
\text { women during early infection }\end{array}$ & \multirow{2}{*}{$\begin{array}{l}\text {-more efficient/robust type } 1 \text { interferon } \\
\text { response in women } \\
\text {-more efficient adaptive immune response } \\
\text {-estrogen effects on transcription }\end{array}$} \\
\hline & $\begin{array}{l}\text { Enrichment of women in post } \\
\text { treatment and spontaneous } \\
\text { controllers }\end{array}$ & \\
\hline & $\begin{array}{l}\text { Enhanced risk of comorbid dis- } \\
\text { ease in HIV-infected women }\end{array}$ & $\begin{array}{l}\text {-greater relative risk of comorbidities driven } \\
\text { by inflammation/immune activation }\end{array}$ \\
\hline \multirow[b]{2}{*}{ Cure } & $\begin{array}{l}\text { Proviral reservoir comparable } \\
\text { but decreased measures of res- } \\
\text { ervoir activity in women }\end{array}$ & $\begin{array}{l}\text {-estrogen control of transcription } \\
\text {-differences in quality of proviral reservoir } \\
\text {-differences in inducibility or T cell subset }\end{array}$ \\
\hline & $\begin{array}{l}\text { Curative interventions targeting } \\
\text { host immune responses }\end{array}$ & $\begin{array}{l}\text {-sex differences in epigenetic structure may } \\
\text { modulate efficacy of chromatin modifiers } \\
\text {-sex is a predictor of checkpoint inhibitor } \\
\text { performance in cancer } \\
\text {-TLR7 agonists may have sex differential ef- } \\
\text { fects given baseline sex differences in activi- } \\
\text { ty and expression }\end{array}$ \\
\hline
\end{tabular}

\section{FUNDING}

Dr. Scully is supported by the NIH/NIAID: K08AI116344 and has received support for this work from amfAR through an ARCHE grant 108842-55-RGRL. 


\section{REFERENCES}

1. Curran JW, Jaffe HW, Hardy AM, Morgan WM, Selik RM, Dondero TJ. Epidemiology of HIV infection and AIDS in the United States. Science. 1988;239(4840):610-6. PubMed PMID: 3340847.

2. WHO. Global Health Observatory data: Number of women living with HIV 2016 [cited 2016 September 21, 2016]. http://www.who.int/hiv/data/epi_core_2016.png?ua=1

3. Marrazzo JM, Ramjee G, Richardson BA, Gomez K, Mgodi N, Nair G, Palanee T, Nakabiito C, van der Straten A, Noguchi L, Hendrix CW, Dai JY, Ganesh S, Mkhize B, Taljaard M, Parikh UM, Piper J, Masse B, Grossman C, Rooney J, Schwartz JL, Watts H, Marzinke MA, Hillier SL, McGowan IM, Chirenje ZM, Team VS. Tenofovir-based preexposure prophylaxis for HIV infection among African women. N Engl J Med. 2015;372(6):509-18. PubMed PMID: 25651245. Pubmed Central PMCID: PMC4341965. doi: 10.1056/NEJMoa1402269

4. Sheth AN, Rolle CP, Gandhi M. HIV pre-exposure prophylaxis for women. J Virus Erad. 2016;2(3):149-55. PubMed PMID: 27482454. Pubmed Central PMCID: PMC4967966.

5. Van Damme L, Corneli A, Ahmed K, Agot K, Lombaard J, Kapiga S, Malahleha M, Owino F, Manongi R, Onyango J, Temu L, Monedi MC, Mak'Oketch P, Makanda M, Reblin I, Makatu SE, Saylor L, Kiernan H, Kirkendale S, Wong C, Grant R, Kashuba A, Nanda K, Mandala J, Fransen K, Deese J, Crucitti T, Mastro TD, Taylor D, Group FE-PS. Preexposure prophylaxis for HIV infection among African women. N Engl J Med. 2012;367(5):411-22. PubMed PMID: 22784040. Pubmed Central PMCID: PMC3687217. doi: 10.1056/NEJMoa1202614

6. Abdool Karim Q, Sibeko S, Baxter C. Preventing HIV infection in women: a global health imperative. Clin Infect Dis. 2010;50 Suppl 3:S122-9. PubMed PMID: 20397940. Pubmed Central PMCID: PMC3021824. doi: 10.1086/651483

7. Patel P, Borkowf CB, Brooks JT, Lasry A, Lansky A, Mermin J. Estimating per-act HIV transmission risk: a systematic review. AIDS. 2014;28(10):1509-19. PubMed PMID: 24809629. doi: 10.1097/QAD.0000000000000298

8. Masson L, Passmore JA, Liebenberg LJ, Werner L, Baxter C, Arnold KB, Williamson C, Little F, Mansoor LE, Naranbhai V, Lauffenburger DA, Ronacher K, Walzl G, Garrett NJ, Williams BL, Couto-Rodriguez M, Hornig M, Lipkin WI, Grobler A, Abdool Karim Q, Abdool Karim SS. Genital inflammation and the risk of HIV acquisition in women. Clin Infect Dis. 2015;61(2):260-9. PubMed PMID: 25900168. Pubmed Central PMCID: PMC4565995. doi: 10.1093/cid/civ298

9. Naranbhai V, Abdool Karim SS, Altfeld M, Samsunder N, Durgiah R, Sibeko S, Abdool Karim Q, Carr WH, team CT. Innate immune activation enhances hiv acquisition in women, diminishing the effectiveness of tenofovir microbicide gel. J Infect Dis. 2012;206(7):993-1001. PubMed PMID: 22829639. Pubmed Central PMCID: PMC3501691. doi: 10.1093/infdis/jis465

10. Arnold KB, Burgener A, Birse K, Romas L, Dunphy LJ, Shahabi K, Abou M, Westmacott GR, McCorrister S, Kwatampora J, Nyanga B, Kimani J, Masson L, Liebenberg LJ, 
Abdool Karim SS, Passmore JA, Lauffenburger DA, Kaul R, McKinnon LR. Increased levels of inflammatory cytokines in the female reproductive tract are associated with altered expression of proteases, mucosal barrier proteins, and an influx of HIV-susceptible target cells. Mucosal Immunol. 2016;9(1):194-205. PubMed PMID: 26104913. doi: $10.1038 / \mathrm{mi} .2015 .51$

11. Selhorst P, Masson L, Ismail SD, Samsunder N, Garrett N, Mansoor LE, Karim QA, Karim SS, Passmore JS, Williamson C. CErvicovaginal inflaMmation Facilitates Acquisition of less infectious HIV variants. Clin Infect Dis. 2016. PubMed PMID: 27694480. doi: 10.1093/cid/ciw663

12. Masson L, Arnold KB, Little F, Mlisana K, Lewis DA, Mkhize N, Gamieldien H, Ngcapu S, Johnson L, Lauffenburger DA, Abdool Karim Q, Abdool Karim SS, Passmore JA. Inflammatory cytokine biomarkers to identify women with asymptomatic sexually transmitted infections and bacterial vaginosis who are at high risk of HIV infection. Sex Transm Infect. 2016;92(3):186-93. PubMed PMID: 26511781. doi: 10.1136/sextrans-2015-052072

13. Masson L, Mlisana K, Little F, Werner L, Mkhize NN, Ronacher K, Gamieldien H, Williamson C, McKinnon LR, Walzl G, Abdool Karim Q, Abdool Karim SS, Passmore JA. Defining genital tract cytokine signatures of sexually transmitted infections and bacterial vaginosis in women at high risk of HIV infection: a cross-sectional study. Sex Transm Infect. 2014;90(8):580-7. PubMed PMID: 25107710. doi: 10.1136/sextrans-2014-051601

14. Brown JM, Wald A, Hubbard A, Rungruengthanakit K, Chipato T, Rugpao S, Mmiro F, Celentano DD, Salata RS, Morrison CS, Richardson BA, Padian NS. Incident and prevalent herpes simplex virus type 2 infection increases risk of HIV acquisition among women in Uganda and Zimbabwe. AIDS. 2007;21(12):1515-23. PubMed PMID: 17630545. doi: 10.1097/QAD.0b013e3282004929

15. Freeman EE, Weiss HA, Glynn JR, Cross PL, Whitworth JA, Hayes RJ. Herpes simplex virus 2 infection increases HIV acquisition in men and women: systematic review and meta-analysis of longitudinal studies. AIDS. 2006;20(1):73-83. PubMed PMID: 16327322.

16. van de Wijgert JH, Morrison CS, Brown J, Kwok C, Van Der Pol B, Chipato T, Byamugisha JK, Padian N, Salata RA. Disentangling contributions of reproductive tract infections to HIV acquisition in African Women. Sex Transm Dis. 2009;36(6):357-64. PubMed PMID: 19434010. doi: 10.1097/OLQ.0b013e3181a4f695

17. Mlisana K, Naicker N, Werner L, Roberts L, van Loggerenberg F, Baxter C, Passmore JA, Grobler AC, Sturm AW, Williamson C, Ronacher K, Walzl G, Abdool Karim SS. Symptomatic vaginal discharge is a poor predictor of sexually transmitted infections and genital tract inflammation in high-risk women in South Africa. J Infect Dis. 2012;206(1):6-14. PubMed PMID: 22517910. Pubmed Central PMCID: PMC3490689. doi: $10.1093 /$ infdis/jis298

18. Anahtar MN, Byrne EH, Doherty KE, Bowman BA, Yamamoto HS, Soumillon M, Padavattan N, Ismail N, Moodley A, Sabatini ME, Ghebremichael MS, Nusbaum C, 
Huttenhower C, Virgin HW, Ndung'u T, Dong KL, Walker BD, Fichorova RN, Kwon DS. Cervicovaginal bacteria are a major modulator of host inflammatory responses in the female genital tract. Immunity. 2015;42(5):965-76. PubMed PMID: 25992865. Pubmed Central PMCID: PMC4461369. doi: 10.1016/j.immuni.2015.04.019

19. Mitchell C, Fredricks D, Agnew K, Hitti J. Hydrogen Peroxide-Producing Lactobacilli Are Associated With Lower Levels of Vaginal Interleukin-1beta, Independent of Bacterial Vaginosis. Sex Transm Dis. 2015;42(7):358-63. PubMed PMID: 26222747. Pubmed Central PMCID: PMC4520248. doi: 10.1097/OLQ.0000000000000298

20. Ravel J, Gajer P, Abdo Z, Schneider GM, Koenig SS, McCulle SL, Karlebach S, Gorle R, Russell J, Tacket CO, Brotman RM, Davis CC, Ault K, Peralta L, Forney LJ. Vaginal microbiome of reproductive-age women. Proc Natl Acad Sci U S A. 2011;108 Suppl 1:4680-7. PubMed PMID: 20534435. Pubmed Central PMCID: PMC3063603. doi: 10.1073/pnas.1002611107

21. Zevin AS, Xie IY, Birse K, Arnold K, Romas L, Westmacott G, Novak RM, McCorrister S, McKinnon LR, Cohen CR, Mackelprang R, Lingappa J, Lauffenburger DA, Klatt NR, Burgener AD. Microbiome Composition and Function Drives Wound-Healing Impairment in the Female Genital Tract. PLoS Pathog. 2016;12(9):e1005889. PubMed PMID: 27656899. doi: 10.1371/journal.ppat.1005889

22. Klatt NR, Cheu R, Birse K, Zevin AS, Perner M, Noel-Romas L, Grobler A, Westmacott G, Xie IY, Butler J, Mansoor L, McKinnon LR, Passmore JS, Abdool Karim Q, Abdool Karim SS, Burgener AD. Vaginal bacteria modify HIV tenofovir microbicide efficacy in African women. Science. 2017;356(6341):938-45. PubMed PMID: 28572388. doi: 10.1126/science.aai9383

23. Hladik F, Burgener A, Ballweber L, Gottardo R, Vojtech L, Fourati S, Dai JY, Cameron MJ, Strobl J, Hughes SM, Hoesley C, Andrew P, Johnson S, Piper J, Friend DR, Ball TB, Cranston RD, Mayer KH, McElrath MJ, McGowan I. Mucosal effects of tenofovir 1\% gel. Elife. 2015;4. PubMed PMID: 25647729. Pubmed Central PMCID: PMC4391502. doi: $10.7554 /$ eLife.04525

24. Kersh EN, Henning T, Vishwanathan SA, Morris M, Butler K, Adams DR, Guenthner P, Srinivasan P, Smith J, Radzio J, Garcia-Lerma JG, Dobard C, Heneine W, McNicholl J. SHIV susceptibility changes during the menstrual cycle of pigtail macaques. J Med Primatol. 2014;43(5):310-6. PubMed PMID: 24779484. Pubmed Central PMCID: PMC4175065. doi: 10.1111/jmp.12124

25. Sodora DL, Gettie A, Miller CJ, Marx PA. Vaginal transmission of SIV: assessing infectivity and hormonal influences in macaques inoculated with cell-free and cell-associated viral stocks. AIDS Res Hum Retroviruses. 1998;14 Suppl 1:S119-23. PubMed PMID: 9581895.

26. Vishwanathan SA, Guenthner PC, Lin CY, Dobard C, Sharma S, Adams DR, Otten RA, Heneine W, Hendry RM, McNicholl JM, Kersh EN. High susceptibility to repeated, low-dose, vaginal SHIV exposure late in the luteal phase of the menstrual cycle of pigtail macaques. J Acquir Immune Defic Syndr. 2011;57(4):261-4. PubMed PMID: 21546848. doi: 10.1097/QAI.0b013e318220ebd3 
27. Butler K, Ritter JM, Ellis S, Morris MR, Hanson DL, McNicholl JM, Kersh EN. A Depot Medroxyprogesterone Acetate Dose That Models Human Use and Its Effect on Vaginal SHIV Acquisition Risk. J Acquir Immune Defic Syndr. 2016;72(4):363-71. PubMed PMID: 27355414. Pubmed Central PMCID: PMC4930010. doi: 10.1097/ QAI.0000000000000975

28. Marx PA, Spira AI, Gettie A, Dailey PJ, Veazey RS, Lackner AA, Mahoney CJ, Miller CJ, Claypool LE, Ho DD, Alexander NJ. Progesterone implants enhance SIV vaginal transmission and early virus load. Nat Med. 1996;2(10):1084-9. PubMed PMID: 8837605.

29. Hild-Petito S, Veazey RS, Larner JM, Reel JR, Blye RP. Effects of two progestin-only contraceptives, Depo-Provera and Norplant-II, on the vaginal epithelium of rhesus monkeys. AIDS Res Hum Retroviruses. 1998;14 Suppl 1:S125-30. PubMed PMID: 9581896.

30. Bahamondes MV, Castro S, Marchi NM, Marcovici M, Andrade LA, Fernandes A, Bahamondes L. Human vaginal histology in long-term users of the injectable contraceptive depot-medroxyprogesterone acetate. Contraception. 2014;90(2):117-22. PubMed PMID: 24613369. doi: 10.1016/j.contraception.2014.01.024

31. Chandra N, Thurman AR, Anderson S, Cunningham TD, Yousefieh N, Mauck C, Doncel GF. Depot medroxyprogesterone acetate increases immune cell numbers and activation markers in human vaginal mucosal tissues. AIDS Res Hum Retroviruses. 2013;29(3):592-601. PubMed PMID: 23189932. Pubmed Central PMCID: PMC3581024. doi: 10.1089/aid.2012.0271

32. Mauck CK, Callahan MM, Baker J, Arbogast K, Veazey R, Stock R, Pan Z, Morrison CS, Chen-Mok M, Archer DF, Gabelnick HL. The effect of one injection of Depo-Provera on the human vaginal epithelium and cervical ectopy. Contraception. 1999;60(1):15-24. PubMed PMID: 10549448.

33. Miller L, Patton DL, Meier A, Thwin SS, Hooton TM, Eschenbach DA. Depomedroxyprogesterone-induced hypoestrogenism and changes in vaginal flora and epithelium. Obstet Gynecol. 2000;96(3):431-9. PubMed PMID: 10960638.

34. Mitchell CM, McLemore L, Westerberg K, Astronomo R, Smythe K, Gardella C, Mack M, Magaret A, Patton D, Agnew K, McElrath MJ, Hladik F, Eschenbach D. Long-term effect of depot medroxyprogesterone acetate on vaginal microbiota, epithelial thickness and HIV target cells. J Infect Dis. 2014;210(4):651-5. PubMed PMID: 24652495. Pubmed Central PMCID: PMC4172039. doi: 10.1093/infdis/jiu176

35. Morrison CS, Chen PL, Kwok C, Baeten JM, Brown J, Crook AM, Van Damme L, Delany-Moretlwe S, Francis SC, Friedland BA, Hayes RJ, Heffron R, Kapiga S, Karim QA, Karpoff S, Kaul R, McClelland RS, McCormack S, McGrath N, Myer L, Rees H, van der Straten A, Watson-Jones D, van de Wijgert JH, Stalter R, Low N. Hormonal contraception and the risk of HIV acquisition: an individual participant data meta-analysis. PLoS Med. 2015;12(1):e1001778. PubMed PMID: 25612136. Pubmed Central PMCID: PMC4303292. doi: 10.1371/journal.pmed.1001778 
36. Polis CB, Curtis KM, Hannaford PC, Phillips SJ, Chipato T, Kiarie JN, Westreich DJ, Steyn PS. Update on hormonal contraceptive methods and risk of HIV acquisition in women: a systematic review of epidemiological evidence, 2016. AIDS. 2016. PubMed PMID: 27500670. doi: 10.1097/QAD.0000000000001228

37. Ralph LJ, McCoy SI, Shiu K, Padian NS. Hormonal contraceptive use and women's risk of HIV acquisition: a meta-analysis of observational studies. Lancet Infect Dis. 2015;15(2):181-9. PubMed PMID: 25578825. Pubmed Central PMCID: PMC4526270. doi: 10.1016/S1473-3099(14)71052-7

38. Byrne EH, Anahtar MN, Cohen KE, Moodley A, Padavattan N, Ismail N, Bowman BA, Olson GS, Mabhula A, Leslie A, Ndung'u T, Walker BD, Ghebremichael MS, Dong KL, Kwon DS. Association between injectable progestin-only contraceptives and HIV acquisition and HIV target cell frequency in the female genital tract in South African women: a prospective cohort study. Lancet Infect Dis. 2016;16(4):441-8. PubMed PMID: 26723758. doi: 10.1016/S1473-3099(15)00429-6

39. Fichorova RN, Chen PL, Morrison CS, Doncel GF, Mendonca K, Kwok C, Chipato T, Salata R, Mauck C. The Contribution of Cervicovaginal Infections to the Immunomodulatory Effects of Hormonal Contraception. MBio. 2015;6(5):e00221-15. PubMed PMID: 26330510. Pubmed Central PMCID: PMC4556810. doi: 10.1128/mBio.0022115

40. Cook IF. Sexual dimorphism of humoral immunity with human vaccines. Vaccine. 2008;26(29-30):3551-5. PubMed PMID: 18524433. doi: 10.1016/j.vaccine.2008.04.054

41. Seligman SJ. Yellow fever virus vaccine-associated deaths in young women. Emerg Infect Dis. 2011;17(10):1891-3. PubMed PMID: 22000363. Pubmed Central PMCID: PMC3310656. doi: 10.3201/eid1710.101789

42. Seligman SJ. Risk groups for yellow fever vaccine-associated viscerotropic disease (YEL-AVD). Vaccine. 2014;32(44):5769-75. PubMed PMID: 25192973. doi: 10.1016/j. vaccine.2014.08.051

43. Stanberry LR, Spruance SL, Cunningham AL, Bernstein DI, Mindel A, Sacks S, Tyring S, Aoki FY, Slaoui M, Denis M, Vandepapeliere P, Dubin G, GlaxoSmithKline Herpes Vaccine Efficacy Study G. Glycoprotein-D-adjuvant vaccine to prevent genital herpes. N Engl J Med. 2002;347(21):1652-61. PubMed PMID: 12444179. doi: 10.1056/NEJMoa011915

44. Rerks-Ngarm S, Pitisuttithum P, Nitayaphan S, Kaewkungwal J, Chiu J, Paris R, Premsri N, Namwat C, de Souza M, Adams E, Benenson M, Gurunathan S, Tartaglia J, McNeil JG, Francis DP, Stablein D, Birx DL, Chunsuttiwat S, Khamboonruang C, Thongcharoen P, Robb ML, Michael NL, Kunasol P, Kim JH, Investigators M-T. Vaccination with ALVAC and AIDSVAX to Prevent HIV-1 Infection in Thailand. New England Journal of Medicine. 2009;361(23):2209-20. PubMed PMID: WOS:000272257100004. doi: 10.1056/NEJMoa0908492

45. Sachdev DD, Ahmed H, Huang YD, Gilbert P, Rerks-Ngarm S, Kaewkungwal J, Nitayaphan S, Michael N, Pitisuttithum P, Robb M, Kim JH, O’Connell R, Frahm 
N, Morgan C, Buchbinder SP. Sex Differences in Immune Variables in the RV144 Trial. Aids Research and Human Retroviruses. 2014;30:A191-A2. PubMed PMID: WOS:000344774402121.

46. Querec TD, Akondy RS, Lee EK, Cao W, Nakaya HI, Teuwen D, Pirani A, Gernert K, Deng J, Marzolf B, Kennedy K, Wu H, Bennouna S, Oluoch H, Miller J, Vencio RZ, Mulligan M, Aderem A, Ahmed R, Pulendran B. Systems biology approach predicts immunogenicity of the yellow fever vaccine in humans. Nat Immunol. 2009;10(1):11625. PubMed PMID: 19029902. Pubmed Central PMCID: PMC4049462. doi: 10.1038/ ni. 1688

47. Klein SL, Jedlicka A, Pekosz A. The Xs and Y of immune responses to viral vaccines. Lancet Infect Dis. 2010;10(5):338-49. PubMed PMID: 20417416. doi: 10.1016/S14733099(10)70049-9

48. Ghorai A, Ghosh U. miRNA gene counts in chromosomes vary widely in a species and biogenesis of miRNA largely depends on transcription or post-transcriptional processing of coding genes. Front Genet. 2014;5:100. PubMed PMID: 24808907. Pubmed Central PMCID: PMC4010735. doi: 10.3389/fgene.2014.00100

49. Hewagama A, Gorelik G, Patel D, Liyanarachchi P, McCune WJ, Somers E, Gonzalez-Rivera T, Michigan Lupus C, Strickland F, Richardson B. Overexpression of X-linked genes in T cells from women with lupus. J Autoimmun. 2013;41:60-71. PubMed PMID: 23434382. Pubmed Central PMCID: PMC3622754. doi: 10.1016/j. jaut.2012.12.006

50. Pinheiro I, Dejager L, Libert C. X-chromosome-located microRNAs in immunity: might they explain male/female differences? The $\mathrm{X}$ chromosome-genomic context may affect X-located miRNAs and downstream signaling, thereby contributing to the enhanced immune response of females. Bioessays. 2011;33(11):791-802. PubMed PMID: 21953569. doi: 10.1002/bies.201100047

51. Klein SL, Flanagan KL. Sex differences in immune responses. Nat Rev Immunol. 2016;16(10):626-38. PubMed PMID: 27546235. doi: 10.1038/nri.2016.90

52. Markle JG, Fish EN. SeXX matters in immunity. Trends Immunol. 2014;35(3):97-104. PubMed PMID: 24239225. doi: 10.1016/j.it.2013.10.006

53. Dillon S, Aggarwal R, Harding JW, Li LJ, Weissman MH, Li S, Cavett JW, Sevier ST, Ojwang JW, D'Souza A, Harley JB, Scofield RH. Klinefelter's syndrome (47,XXY) among men with systemic lupus erythematosus. Acta Paediatr. 2011;100(6):819-23. PubMed PMID: 21375582. doi: 10.1111/j.1651-2227.2011.02185.x

54. Spolarics Z, Pena G, Qin Y, Donnelly RJ, Livingston DH. Inherent X-Linked Genetic Variability and Cellular Mosaicism Unique to Females Contribute to Sex-Related Differences in the Innate Immune Response. Front Immunol. 2017;8:1455. PubMed PMID: 29180997. Pubmed Central PMCID: PMC5694032. doi: 10.3389/fimmu.2017.01455

55. Dunford A, Weinstock DM, Savova V, Schumacher SE, Cleary JP, Yoda A, Sullivan TJ, Hess JM, Gimelbrant AA, Beroukhim R, Lawrence MS, Getz G, Lane AA. Tumor-sup- 
pressor genes that escape from X-inactivation contribute to cancer sex bias. Nat Genet. 2017;49(1):10-6. PubMed PMID: 27869828. Pubmed Central PMCID: PMC5206905. doi: $10.1038 /$ ng.3726

56. Carrel L, Brown CJ. When the Lyon(ized chromosome) roars: ongoing expression from an inactive X chromosome. Philos Trans R Soc Lond B Biol Sci. 2017;372(1733). PubMed PMID: 28947654. Pubmed Central PMCID: PMC5627157. doi: 10.1098/ rstb.2016.0355

57. Souyris M, Cenac C, Azar P, Daviaud D, Canivet A, Grunenwald S, Pienkowski C, Chaumeil J, Mejia JE, Guery JC. TLR7 escapes X chromosome inactivation in immune cells. Sci Immunol. 2018;3(19). PubMed PMID: 29374079. doi: 10.1126/sciimmunol. aap8855

58. Griesbeck M, Ziegler S, Laffont S, Smith N, Chauveau L, Tomezsko P, Sharei A, Kourjian G, Porichis F, Hart M, Palmer CD, Sirignano M, Beisel C, Hildebrandt H, Cenac C, Villani AC, Diefenbach TJ, Le Gall S, Schwartz O, Herbeuval JP, Autran B, Guery JC, Chang JJ, Altfeld M. Sex Differences in Plasmacytoid Dendritic Cell Levels of IRF5 Drive Higher IFN-alpha Production in Women. J Immunol. 2015;195(11):5327-36. PubMed PMID: 26519527. Pubmed Central PMCID: PMC4654231. doi: 10.4049/jimmunol.1501684

59. Katzenstein DA, Hammer SM, Hughes MD, Gundacker H, Jackson JB, Fiscus S, Rasheed S, Elbeik T, Reichman R, Japour A, Merigan TC, Hirsch MS. The relation of virologic and immunologic markers to clinical outcomes after nucleoside therapy in HIV-infected adults with 200 to 500 CD4 cells per cubic millimeter. AIDS Clinical Trials Group Study 175 Virology Study Team. N Engl J Med. 1996;335(15):1091-8. PubMed PMID: 8813039. doi: 10.1056/NEJM199610103351502

60. Evans JS, Nims T, Cooley J, Bradley W, Jagodzinski L, Zhou S, Melcher GP, Burke DS, Vahey M. Serum levels of virus burden in early-stage human immunodeficiency virus type 1 disease in women. J Infect Dis. 1997;175(4):795-800. PubMed PMID: 9086132.

61. Farzadegan H, Hoover DR, Astemborski J, Lyles CM, Margolick JB, Markham RB, Quinn TC, Vlahov D. Sex differences in HIV-1 viral load and progression to AIDS. Lancet. 1998;352(9139):1510-4. PubMed PMID: 9820299. doi: 10.1016/S01406736(98)02372-1

62. Lyles CM, Dorrucci M, Vlahov D, Pezzotti P, Angarano G, Sinicco A, Alberici F, Alcorn TM, Vella S, Rezza G. Longitudinal human immunodeficiency virus type 1 load in the italian seroconversion study: correlates and temporal trends of virus load. J Infect Dis. 1999;180(4):1018-24. PubMed PMID: 10479126. doi: 10.1086/314980

63. Sterling TR, Lyles CM, Vlahov D, Astemborski J, Margolick JB, Quinn TC. Sex differences in longitudinal human immunodeficiency virus type 1 RNA levels among seroconverters. J Infect Dis. 1999;180(3):666-72. PubMed PMID: 10438353. doi: $10.1086 / 314967$

64. Sterling TR, Vlahov D, Astemborski J, Hoover DR, Margolick JB, Quinn TC. Initial plasma HIV-1 RNA levels and progression to AIDS in women and men. N Engl J Med. 2001;344(10):720-5. PubMed PMID: 11236775. doi: 10.1056/NEJM200103083441003 
65. Anastos K, Gange SJ, Lau B, Weiser B, Detels R, Giorgi JV, Margolick JB, Cohen M, Phair J, Melnick S, Rinaldo CR, Kovacs A, Levine A, Landesman S, Young M, Munoz A, Greenblatt RM. Association of race and gender with HIV-1 RNA levels and immunologic progression. J Acquir Immune Defic Syndr. 2000;24(3):218-26. PubMed PMID: 10969345.

66. Bush CE, Donovan RM, Markowitz N, Baxa D, Kvale P, Saravolatz LD. Gender is not a factor in serum human immunodeficiency virus type 1 RNA levels in patients with viremia. J Clin Microbiol. 1996;34(4):970-2. PubMed PMID: 8815119. Pubmed Central PMCID: PMC228928.

67. Moore RD, Cheever L, Keruly JC, Chaisson RE. Lack of sex difference in CD4 to HIV1 RNA viral load ratio. Lancet. 1999;353(9151):463-4. PubMed PMID: 9989720. doi: 10.1016/S0140-6736(98)05379-3

68. Gandhi M, Bacchetti P, Miotti P, Quinn TC, Veronese F, Greenblatt RM. Does patient sex affect human immunodeficiency virus levels? Clin Infect Dis. 2002;35(3):313-22. PubMed PMID: 12115098. doi: 10.1086/341249

69. Napravnik S, Poole C, Thomas JC, Eron JJ, Jr. Gender difference in HIV RNA levels: a meta-analysis of published studies. J Acquir Immune Defic Syndr. 2002;31(1):11-9. PubMed PMID: 12352145.

70. Carrington M, Walker BD. Immunogenetics of spontaneous control of HIV. Annu Rev Med. 2012;63:131-45. PubMed PMID: 22248321. Pubmed Central PMCID: PMC3725592. doi: 10.1146/annurev-med-062909-130018

71. Lobritz MA, Lassen KG, Arts EJ. HIV-1 replicative fitness in elite controllers. Curr Opin HIV AIDS. 2011;6(3):214-20. PubMed PMID: 21430530. doi: 10.1097/COH. 0b013e3283454cf5

72. McLaren PJ, Carrington M. The impact of host genetic variation on infection with HIV-1. Nat Immunol. 2015;16(6):577-83. PubMed PMID: 25988890. doi: 10.1038/ ni. 3147

73. O'Connell KA, Bailey JR, Blankson JN. Elucidating the elite: mechanisms of control in HIV-1 infection. Trends Pharmacol Sci. 2009;30(12):631-7. PubMed PMID: 19837464. doi: 10.1016/j.tips.2009.09.005

74. Zaunders J, Dyer WB, Churchill M. The Sydney Blood Bank Cohort: implications for viral fitness as a cause of elite control. Curr Opin HIV AIDS. 2011;6(3):151-6. PubMed PMID: 21378562. doi: 10.1097/COH.0b013e3283454d5b

75. Crowell TA, Gebo KA, Blankson JN, Korthuis PT, Yehia BR, Rutstein RM, Moore RD, Sharp V, Nijhawan AE, Mathews WC, Hanau LH, Corales RB, Beil R, Somboonwit C, Edelstein H, Allen SL, Berry SA, Network HIVR. Hospitalization Rates and Reasons Among HIV Elite Controllers and Persons With Medically Controlled HIV Infection. J Infect Dis. 2015;211(11):1692-702. PubMed PMID: 25512624. Pubmed Central PMCID: PMC4447832. doi: 10.1093/infdis/jiu809

76. Madec Y, Boufassa F, Porter K, Meyer L, Collaboration C. Spontaneous control of viral load and CD4 cell count progression among HIV-1 seroconverters. AIDS. 2005;19(17):2001-7. PubMed PMID: 16260907. 
77. Giefing-Kroll C, Berger P, Lepperdinger G, Grubeck-Loebenstein B. How sex and age affect immune responses, susceptibility to infections, and response to vaccination. Aging Cell. 2015;14(3):309-21. PubMed PMID: 25720438. Pubmed Central PMCID: PMC4406660. doi: 10.1111/acel.12326

78. vom Steeg LG, Klein SL. SeXX Matters in Infectious Disease Pathogenesis. PLoS Pathog. 2016;12(2):e1005374. PubMed PMID: 26891052. Pubmed Central PMCID: PMC4759457. doi: 10.1371/journal.ppat.1005374

79. International HIVCS, Pereyra F, Jia X, McLaren PJ, Telenti A, de Bakker PI, Walker BD, Ripke S, Brumme CJ, Pulit SL, Carrington M, Kadie CM, Carlson JM, Heckerman D, Graham RR, Plenge RM, Deeks SG, Gianniny L, Crawford G, Sullivan J, Gonzalez E, Davies L, Camargo A, Moore JM, Beattie N, Gupta S, Crenshaw A, Burtt NP, Guiducci C, Gupta N, Gao X, Qi Y, Yuki Y, Piechocka-Trocha A, Cutrell E, Rosenberg R, Moss KL, Lemay P, O’Leary J, Schaefer T, Verma P, Toth I, Block B, Baker B, Rothchild A, Lian J, Proudfoot J, Alvino DM, Vine S, Addo MM, Allen TM, Altfeld M, Henn MR, Le Gall S, Streeck H, Haas DW, Kuritzkes DR, Robbins GK, Shafer RW, Gulick RM, Shikuma CM, Haubrich R, Riddler S, Sax PE, Daar ES, Ribaudo HJ, Agan B, Agarwal S, Ahern RL, Allen BL, Altidor S, Altschuler EL, Ambardar S, Anastos K, Anderson B, Anderson V, Andrady U, Antoniskis D, Bangsberg D, Barbaro D, Barrie W, Bartczak J, Barton S, Basden P, Basgoz N, Bazner S, Bellos NC, Benson AM, Berger J, Bernard NF, Bernard AM, Birch C, Bodner SJ, Bolan RK, Boudreaux ET, Bradley M, Braun JF, Brndjar JE, Brown SJ, Brown K, Brown ST, Burack J, Bush LM, Cafaro V, Campbell O, Campbell J, Carlson RH, Carmichael JK, Casey KK, Cavacuiti C, Celestin G, Chambers ST, Chez N, Chirch LM, Cimoch PJ, Cohen D, Cohn LE, Conway B, Cooper DA, Cornelson B, Cox DT, Cristofano MV, Cuchural G, Jr., Czartoski JL, Dahman JM, Daly JS, Davis BT, Davis K, Davod SM, DeJesus E, Dietz CA, Dunham E, Dunn ME, Ellerin TB, Eron JJ, Fangman JJ, Farel CE, Ferlazzo H, Fidler S, Fleenor-Ford A, Frankel R, Freedberg KA, French NK, Fuchs JD, Fuller JD, Gaberman J, Gallant JE, Gandhi RT, Garcia E, Garmon D, Gathe JC, Jr., Gaultier CR, Gebre W, Gilman FD, Gilson I, Goepfert PA, Gottlieb MS, Goulston C, Groger RK, Gurley TD, Haber S, Hardwicke R, Hardy WD, Harrigan PR, Hawkins TN, Heath S, Hecht FM, Henry WK, Hladek M, Hoffman RP, Horton JM, Hsu RK, Huhn GD, Hunt P, Hupert MJ, Illeman ML, Jaeger H, Jellinger RM, John M, Johnson JA, Johnson KL, Johnson H, Johnson K, Joly J, Jordan WC, Kauffman CA, Khanlou H, Killian RK, Kim AY, Kim DD, Kinder CA, Kirchner JT, Kogelman L, Kojic EM, Korthuis PT, Kurisu W, Kwon DS, LaMar M, Lampiris H, Lanzafame M, Lederman MM, Lee DM, Lee JM, Lee MJ, Lee ET, Lemoine J, Levy JA, Llibre JM, Liguori MA, Little SJ, Liu AY, Lopez AJ, Loutfy MR, Loy D, Mohammed DY, Man A, Mansour MK, Marconi VC, Markowitz M, Marques R, Martin JN, Martin HL, Jr., Mayer KH, McElrath MJ, McGhee TA, McGovern BH, McGowan K, McIntyre D, McLeod GX, Menezes P, Mesa G, Metroka CE, Meyer-Olson D, Miller AO, Montgomery K, Mounzer KC, Nagami EH, Nagin I, Nahass RG, Nelson MO, Nielsen C, Norene DL, O’Connor DH, Ojikutu BO, Okulicz J, Oladehin OO, Oldfield EC, 3rd, Olender SA, Ostrowski M, Owen WF, Jr., Pae E, Parsonnet J, Pavlatos AM, Perlmutter AM, Pierce MN, Pincus JM, Pisani L, Price LJ, Proia L, Prokesch RC, Pujet HC, Ramgopal M, Rathod A, Rausch M, Ravishan- 
kar J, Rhame FS, Richards CS, Richman DD, Rodes B, Rodriguez M, Rose RC, 3rd, Rosenberg ES, Rosenthal D, Ross PE, Rubin DS, Rumbaugh E, Saenz L, Salvaggio MR, Sanchez WC, Sanjana VM, Santiago S, Schmidt W, Schuitemaker H, Sestak PM, Shalit P, Shay W, Shirvani VN, Silebi VI, Sizemore JM, Jr., Skolnik PR, Sokol-Anderson M, Sosman JM, Stabile P, Stapleton JT, Starrett S, Stein F, Stellbrink HJ, Sterman FL, Stone VE, Stone DR, Tambussi G, Taplitz RA, Tedaldi EM, Telenti A, Theisen W, Torres R, Tosiello L, Tremblay C, Tribble MA, Trinh PD, Tsao A, Ueda P, Vaccaro A, Valadas E, Vanig TJ, Vecino I, Vega VM, Veikley W, Wade BH, Walworth C, Wanidworanun C, Ward DJ, Warner DA, Weber RD, Webster D, Weis S, Wheeler DA, White DJ, Wilkins E, Winston A, Wlodaver CG, van't Wout A, Wright DP, Yang OO, Yurdin DL, Zabukovic BW, Zachary KC, Zeeman B, Zhao M. The major genetic determinants of HIV-1 control affect HLA class I peptide presentation. Science. 2010;330(6010):15517. PubMed PMID: 21051598. Pubmed Central PMCID: PMC3235490. doi: 10.1126/ science. 1195271

80. Ruel TD, Zanoni BC, Ssewanyana I, Cao H, Havlir DV, Kamya M, Achan J, Charlebois ED, Feeney ME. Sex differences in HIV RNA level and CD4 cell percentage during childhood. Clin Infect Dis. 2011;53(6):592-9. PubMed PMID: 21840929. Pubmed Central PMCID: PMC3160805. doi: 10.1093/cid/cir484

81. Konig IR, Loley C, Erdmann J, Ziegler A. How to include chromosome X in your genome-wide association study. Genet Epidemiol. 2014;38(2):97-103. PubMed PMID: 24408308. doi: 10.1002/gepi.21782

82. Wise AL, Gyi L, Manolio TA. eXclusion: toward integrating the X chromosome in genome-wide association analyses. Am J Hum Genet. 2013;92(5):643-7. PubMed PMID: 23643377. Pubmed Central PMCID: PMC3644627. doi: 10.1016/j.ajhg.2013.03.017

83. Curno MJ, Rossi S, Hodges-Mameletzis I, Johnston R, Price MA, Heidari S. A Systematic Review of the Inclusion (or Exclusion) of Women in HIV Research: From Clinical Studies of Antiretrovirals and Vaccines to Cure Strategies. J Acquir Immune Defic Syndr. 2016;71(2):181-8. PubMed PMID: 26361171. doi: 10.1097/ QAI.0000000000000842

84. Sterling TR, Pisell-Noland T, Perez JL, Astemborski J, McGriff JR, Nutting L, Hoover DR, Vlahov D, Bollinger RC. Sex-based differences in T lymphocyte responses in HIV-1-seropositive individuals. J Infect Dis. 2005;191(6):881-5. PubMed PMID: 15717262. doi: $10.1086 / 427827$

85. Sankaran-Walters S, Macal M, Grishina I, Nagy L, Goulart L, Coolidge K, Li J, Fenton A, Williams T, Miller MK, Flamm J, Prindiville T, George M, Dandekar S. Sex differences matter in the gut: effect on mucosal immune activation and inflammation. Biol Sex Differ. 2013;4(1):10. PubMed PMID: 23651648. Pubmed Central PMCID: PMC3652739. doi: 10.1186/2042-6410-4-10

86. Hewagama A, Patel D, Yarlagadda S, Strickland FM, Richardson BC. Stronger inflammatory/cytotoxic T-cell response in women identified by microarray analysis. Genes Immun. 2009;10(5):509-16. PubMed PMID: 19279650. Pubmed Central PMCID: PMC2735332. doi: 10.1038/gene.2009.12 
87. Giorgi JV, Hultin LE, McKeating JA, Johnson TD, Owens B, Jacobson LP, Shih R, Lewis J, Wiley DJ, Phair JP, Wolinsky SM, Detels R. Shorter survival in advanced human immunodeficiency virus type 1 infection is more closely associated with T lymphocyte activation than with plasma virus burden or virus chemokine coreceptor usage. J Infect Dis. 1999;179(4):859-70. PubMed PMID: 10068581. doi: 10.1086/314660

88. Deeks SG, Kitchen CM, Liu L, Guo H, Gascon R, Narvaez AB, Hunt P, Martin JN, Kahn JO, Levy J, McGrath MS, Hecht FM. Immune activation set point during early HIV infection predicts subsequent CD4+ T-cell changes independent of viral load. Blood. 2004;104(4):942-7. PubMed PMID: 15117761. doi: 10.1182/ blood-2003-09-3333

89. Meier A, Chang JJ, Chan ES, Pollard RB, Sidhu HK, Kulkarni S, Wen TF, Lindsay RJ, Orellana L, Mildvan D, Bazner S, Streeck H, Alter G, Lifson JD, Carrington M, Bosch RJ, Robbins GK, Altfeld M. Sex differences in the Toll-like receptor-mediated response of plasmacytoid dendritic cells to HIV-1. Nat Med. 2009;15(8):955-9. PubMed PMID: 19597505. Pubmed Central PMCID: PMC2821111. doi: 10.1038/nm.2004

90. Laffont S, Rouquie N, Azar P, Seillet C, Plumas J, Aspord C, Guery JC. X-Chromosome complement and estrogen receptor signaling independently contribute to the enhanced TLR7-mediated IFN-alpha production of plasmacytoid dendritic cells from women. J Immunol. 2014;193(11):5444-52. PubMed PMID: 25339659. doi: 10.4049/ jimmunol.1303400

91. Seillet C, Laffont S, Tremollieres F, Rouquie N, Ribot C, Arnal JF, Douin-Echinard V, Gourdy P, Guery JC. The TLR-mediated response of plasmacytoid dendritic cells is positively regulated by estradiol in vivo through cell-intrinsic estrogen receptor alpha signaling. Blood. 2012;119(2):454-64. PubMed PMID: 22096248. doi: 10.1182/ blood-2011-08-371831

92. Hughes GC, Thomas S, Li C, Kaja MK, Clark EA. Cutting edge: progesterone regulates IFN-alpha production by plasmacytoid dendritic cells. J Immunol. 2008;180(4):202933. PubMed PMID: 18250406.

93. Jost S, Altfeld M. Control of human viral infections by natural killer cells. Annu Rev Immunol. 2013;31:163-94. PubMed PMID: 23298212. doi: 10.1146/annurev-immunol-032712-100001

94. Scully E, Alter G. NK Cells in HIV Disease. Curr HIV/AIDS Rep. 2016;13(2):85-94. PubMed PMID: 27002078. Pubmed Central PMCID: PMC4821863. doi: 10.1007/ s11904-016-0310-3

95. Hiby SE, Apps R, Sharkey AM, Farrell LE, Gardner L, Mulder A, Claas FH, Walker JJ, Redman CW, Morgan L, Tower C, Regan L, Moore GE, Carrington M, Moffett A. Maternal activating KIRs protect against human reproductive failure mediated by fetal HLA-C2. J Clin Invest. 2010;120(11):4102-10. PubMed PMID: 20972337. Pubmed Central PMCID: PMC2964995. doi: 10.1172/JCI43998

96. Moffett A, Colucci F. Uterine NK cells: active regulators at the maternal-fetal interface. J Clin Invest. 2014;124(5):1872-9. PubMed PMID: 24789879. Pubmed Central PMCID: PMC4001528. doi: 10.1172/JCI68107 
97. Moffett A, Colucci F. Co-evolution of NK receptors and HLA ligands in humans is driven by reproduction. Immunol Rev. 2015;267(1):283-97. PubMed PMID: 26284484. doi: $10.1111 /$ imr.12323

98. Al-Attar A, Presnell SR, Peterson CA, Thomas DT, Lutz CT. The effect of sex on immune cells in healthy aging: Elderly women have more robust natural killer lymphocytes than do elderly men. Mech Ageing Dev. 2016;156:25-33. PubMed PMID: 27059724. doi: 10.1016/j.mad.2016.04.001

99. Yovel G, Shakhar K, Ben-Eliyahu S. The effects of sex, menstrual cycle, and oral contraceptives on the number and activity of natural killer cells. Gynecol Oncol. 2001;81(2):254-62. PubMed PMID: 11330959. doi: 10.1006/gyno.2001.6153

100. Horowitz A, Strauss-Albee DM, Leipold M, Kubo J, Nemat-Gorgani N, Dogan OC, Dekker CL, Mackey S, Maecker H, Swan GE, Davis MM, Norman PJ, Guethlein LA, Desai M, Parham P, Blish CA. Genetic and environmental determinants of human NK cell diversity revealed by mass cytometry. Sci Transl Med. 2013;5(208):208ra145. PubMed PMID: 24154599. Pubmed Central PMCID: PMC3918221. doi: 10.1126/scitranslmed.3006702

101. Strauss-Albee DM, Horowitz A, Parham P, Blish CA. Coordinated regulation of NK receptor expression in the maturing human immune system. J Immunol. 2014;193(10):4871-9. PubMed PMID: 25288567. Pubmed Central PMCID: PMC4225175. doi: 10.4049/jimmunol.1401821

102. Wilson EM, Singh A, Hullsiek KH, Gibson D, Henry WK, Lichtenstein K, Onen NF, Kojic E, Patel P, Brooks JT, Sereti I, Baker JV, Study to Understand the Natural History of HIVAitEoETI. Monocyte-activation phenotypes are associated with biomarkers of inflammation and coagulation in chronic HIV infection. J Infect Dis. 2014;210(9):1396-406. PubMed PMID: 24813472. Pubmed Central PMCID: PMC4207864. doi: 10.1093/infdis/jiu275

103. Funderburg NT, Mayne E, Sieg SF, Asaad R, Jiang W, Kalinowska M, Luciano AA, Stevens W, Rodriguez B, Brenchley JM, Douek DC, Lederman MM. Increased tissue factor expression on circulating monocytes in chronic HIV infection: relationship to in vivo coagulation and immune activation. Blood. 2010;115(2):161-7. PubMed PMID: 19828697. Pubmed Central PMCID: PMC2808148. doi: 10.1182/ blood-2009-03-210179

104. Funderburg NT, Zidar DA, Shive C, Lioi A, Mudd J, Musselwhite LW, Simon DI, Costa MA, Rodriguez B, Sieg SF, Lederman MM. Shared monocyte subset phenotypes in HIV-1 infection and in uninfected subjects with acute coronary syndrome. Blood. 2012;120(23):4599-608. PubMed PMID: 23065151. Pubmed Central PMCID: PMC3512236. doi: 10.1182/blood-2012-05-433946

105. Miller YI, Choi SH, Wiesner P, Fang L, Harkewicz R, Hartvigsen K, Boullier A, Gonen A, Diehl CJ, Que X, Montano E, Shaw PX, Tsimikas S, Binder CJ, Witztum JL. Oxidation-specific epitopes are danger-associated molecular patterns recognized by pattern 
recognition receptors of innate immunity. Circ Res. 2011;108(2):235-48. PubMed PMID: 21252151. Pubmed Central PMCID: PMC3075542. doi: 10.1161/CIRCRESAHA.110.223875

106. Distelmaier K, Schrutka L, Wurm R, Seidl V, Arfsten H, Cho A, Manjunatha S, Perkmann T, Strunk G, Lang IM, Adlbrecht C. Gender-related impact on outcomes of high density lipoprotein in acute ST-elevation myocardial infarction. Atherosclerosis. 2016;251:460-6. PubMed PMID: 27381657. doi: 10.1016/j.atherosclerosis.2016.06.037

107. Heimbeck I, Hofer TP, Eder C, Wright AK, Frankenberger M, Marei A, Boghdadi G, Scherberich J, Ziegler-Heitbrock L. Standardized single-platform assay for human monocyte subpopulations: Lower CD14+CD16++ monocytes in females. Cytometry A. 2010;77(9):823-30. PubMed PMID: 20662093. doi: 10.1002/cyto.a.20942

108. Jiang W, Zhang L, Lang R, Li Z, Gilkeson G. Sex differences in monocyte activation in systemic lupus erythematosus (SLE). PLoS One. 2014;9(12):e114589. PubMed PMID: 25485543. Pubmed Central PMCID: PMC4259347. doi: 10.1371/journal. pone.0114589

109. Krebs SJ, Slike BM, Sithinamsuwan P, Allen IE, Chalermchai T, Tipsuk S, Phanuphak N, Jagodzinski L, Kim JH, Ananworanich J, Marovich MA, Valcour VG, team Ss. Sex differences in soluble markers vary before and after the initiation of antiretroviral therapy in chronically HIV-infected individuals. AIDS. 2016;30(10):1533-42. PubMed PMID: 26990631. Pubmed Central PMCID: PMC4889571. doi: 10.1097/ QAD.0000000000001096

110. Li JZ, Arnold KB, Lo J, Dugast AS, Plants J, Ribaudo HJ, Cesa K, Heisey A, Kuritzkes DR, Lauffenburger DA, Alter G, Landay A, Grinspoon S, Pereyra F. Differential levels of soluble inflammatory markers by human immunodeficiency virus controller status and demographics. Open Forum Infect Dis. 2015;2(1):ofu117. PubMed PMID: 25884005. Pubmed Central PMCID: PMC4396431. doi: 10.1093/ofid/ofu117

111. Mathad JS, Gupte N, Balagopal A, Asmuth D, Hakim J, Santos B, Riviere C, Hosseinipour M, Sugandhavesa P, Infante R, Pillay S, Cardoso SW, Mwelase N, Pawar J, Berendes S, Kumarasamy N, Andrade BB, Campbell TB, Currier JS, Cohn SE, Gupta A, New Work Concept S, Teams ACTGAS. Sex-Related Differences in Inflammatory and Immune Activation Markers Before and After Combined Antiretroviral Therapy Initiation. J Acquir Immune Defic Syndr. 2016;73(2):123-9. PubMed PMID: 27258230. Pubmed Central PMCID: PMC5023467. doi: 10.1097/QAI.0000000000001095

112. Sakiani S, Olsen NJ, Kovacs WJ. Gonadal steroids and humoral immunity. Nat Rev Endocrinol. 2013;9(1):56-62. PubMed PMID: 23183675. doi: 10.1038/nrendo.2012.206

113. Furman D, Hejblum BP, Simon N, Jojic V, Dekker CL, Thiebaut R, Tibshirani RJ, Davis MM. Systems analysis of sex differences reveals an immunosuppressive role for testosterone in the response to influenza vaccination. Proc Natl Acad Sci U S A. 2014;111(2):869-74. PubMed PMID: 24367114. Pubmed Central PMCID: PMC3896147. doi: 10.1073/pnas.1321060111

114. Landais E, Huang X, Havenar-Daughton C, Murrell B, Price MA, Wickramasinghe L, Ramos A, Bian CB, Simek M, Allen S, Karita E, Kilembe W, Lakhi S, Inambao M, 
Kamali A, Sanders EJ, Anzala O, Edward V, Bekker LG, Tang J, Gilmour J, Kosakovsky-Pond SL, Phung P, Wrin T, Crotty S, Godzik A, Poignard P. Broadly Neutralizing Antibody Responses in a Large Longitudinal Sub-Saharan HIV Primary Infection Cohort. PLoS Pathog. 2016;12(1):e1005369. PubMed PMID: 26766578. Pubmed Central PMCID: PMC4713061. doi: 10.1371/journal.ppat.1005369

115. Moore PL, Williamson C, Morris L. Virological features associated with the development of broadly neutralizing antibodies to HIV-1. Trends Microbiol. 2015;23(4):20411. PubMed PMID: 25572881. Pubmed Central PMCID: PMC4380704. doi: 10.1016/j. tim.2014.12.007

116. Haynes BF, Gilbert PB, McElrath MJ, Zolla-Pazner S, Tomaras GD, Alam SM, Evans DT, Montefiori DC, Karnasuta C, Sutthent R, Liao HX, DeVico AL, Lewis GK, Williams C, Pinter A, Fong Y, Janes H, DeCamp A, Huang Y, Rao M, Billings E, Karasavvas N, Robb ML, Ngauy V, de Souza MS, Paris R, Ferrari G, Bailer RT, Soderberg KA, Andrews C, Berman PW, Frahm N, De Rosa SC, Alpert MD, Yates NL, Shen X, Koup RA, Pitisuttithum P, Kaewkungwal J, Nitayaphan S, Rerks-Ngarm S, Michael $\mathrm{NL}$, Kim JH. Immune-correlates analysis of an HIV-1 vaccine efficacy trial. N Engl J Med. 2012;366(14):1275-86. PubMed PMID: 22475592. Pubmed Central PMCID: PMC3371689. doi: 10.1056/NEJMoa1113425

117. Chung AW, Ghebremichael M, Robinson H, Brown E, Choi I, Lane S, Dugast AS, Schoen MK, Rolland M, Suscovich TJ, Mahan AE, Liao L, Streeck H, Andrews C, Rerks-Ngarm S, Nitayaphan S, de Souza MS, Kaewkungwal J, Pitisuttithum P, Francis D, Michael NL, Kim JH, Bailey-Kellogg C, Ackerman ME, Alter G. Polyfunctional Fc-effector profiles mediated by IgG subclass selection distinguish RV144 and VAX003 vaccines. Sci Transl Med. 2014;6(228):228ra38. PubMed PMID: 24648341. doi: 10.1126/ scitranslmed.3007736

118. Nimmerjahn F, Ravetch JV. Fcgamma receptors as regulators of immune responses. Nat Rev Immunol. 2008;8(1):34-47. PubMed PMID: 18064051. doi: 10.1038/nri2206

119. Ackerman ME, Alter G. Opportunities to exploit non-neutralizing HIV-specific antibody activity. Curr HIV Res. 2013;11(5):365-77. PubMed PMID: 24191934. Pubmed Central PMCID: PMC4955549.

120. Chen G, Wang Y, Qiu L, Qin X, Liu H, Wang X, Wang Y, Song G, Li F, Guo Y, Li F, Guo S, Li Z. Human IgG Fc-glycosylation profiling reveals associations with age, sex, female sex hormones and thyroid cancer. J Proteomics. 2012;75(10):2824-34. PubMed PMID: 22365975. doi: 10.1016/j.jprot.2012.02.001

121. van de Geijn FE, Wuhrer M, Selman MH, Willemsen SP, de Man YA, Deelder AM, Hazes JM, Dolhain RJ. Immunoglobulin G galactosylation and sialylation are associated with pregnancy-induced improvement of rheumatoid arthritis and the postpartum flare: results from a large prospective cohort study. Arthritis Res Ther. 2009;11(6):R193. PubMed PMID: 20015375. Pubmed Central PMCID: PMC3003510. doi: $10.1186 / \operatorname{ar} 2892$

122. Alavi A, Arden N, Spector TD, Axford JS. Immunoglobulin G glycosylation and clinical outcome in rheumatoid arthritis during pregnancy. J Rheumatol. 2000;27(6):137985. PubMed PMID: 10852257. 
123. Carson DD, Farrar JD, Laidlaw J, Wright DA. Selective activation of the N-glycosylation apparatus in uteri by estrogen. J Biol Chem. 1990;265(5):2947-55. PubMed PMID: 2303433.

124. Ercan A, Kohrt WM, Cui J, Deane KD, Pezer M, Yu EW, Hausmann JS, Campbell H, Kaiser UB, Rudd PM, Lauc G, Wilson JF, Finkelstein JS, Nigrovic PA. Estrogens regulate glycosylation of IgG in women and men. JCI Insight. 2017;2(4):e89703. PubMed PMID: 28239652. Pubmed Central PMCID: PMC5313059. doi: 10.1172/jci. insight.89703

125. Brenchley JM, Price DA, Schacker TW, Asher TE, Silvestri G, Rao S, Kazzaz Z, Bornstein E, Lambotte O, Altmann D, Blazar BR, Rodriguez B, Teixeira-Johnson L, Landay A, Martin JN, Hecht FM, Picker LJ, Lederman MM, Deeks SG, Douek DC. Microbial translocation is a cause of systemic immune activation in chronic HIV infection. Nat Med. 2006;12(12):1365-71. PubMed PMID: 17115046. doi: 10.1038/nm1511

126. Hummelen R, Changalucha J, Butamanya NL, Koyama TE, Cook A, Habbema JD, Reid G. Effect of 25 weeks probiotic supplementation on immune function of HIV patients. Gut Microbes. 2011;2(2):80-5. PubMed PMID: 21637031.

127. Klatt NR, Canary LA, Sun X, Vinton CL, Funderburg NT, Morcock DR, Quinones M, Deming CB, Perkins M, Hazuda DJ, Miller MD, Lederman MM, Segre JA, Lifson JD, Haddad EK, Estes JD, Brenchley JM. Probiotic/prebiotic supplementation of antiretrovirals improves gastrointestinal immunity in SIV-infected macaques. J Clin Invest. 2013;123(2):903-7. PubMed PMID: 23321668. Pubmed Central PMCID: PMC3561826. doi: 10.1172/JCI66227

128. Schunter M, Chu H, Hayes TL, McConnell D, Crawford SS, Luciw PA, Bengmark S, Asmuth DM, Brown J, Bevins CL, Shacklett BL, Critchfield JW. Randomized pilot trial of a synbiotic dietary supplement in chronic HIV-1 infection. BMC Complement Altern Med. 2012;12:84. PubMed PMID: 22747752. Pubmed Central PMCID: PMC3414771. doi: 10.1186/1472-6882-12-84

129. Markle JG, Frank DN, Mortin-Toth S, Robertson CE, Feazel LM, Rolle-Kampczyk U, von Bergen M, McCoy KD, Macpherson AJ, Danska JS. Sex differences in the gut microbiome drive hormone-dependent regulation of autoimmunity. Science. 2013;339(6123):1084-8. PubMed PMID: 23328391. doi: 10.1126/science.1233521

130. Yurkovetskiy L, Burrows M, Khan AA, Graham L, Volchkov P, Becker L, Antonopoulos D, Umesaki Y, Chervonsky AV. Gender bias in autoimmunity is influenced by microbiota. Immunity. 2013;39(2):400-12. PubMed PMID: 23973225. Pubmed Central PMCID: PMC3822899. doi: 10.1016/j.immuni.2013.08.013

131. Dominianni C, Sinha R, Goedert JJ, Pei Z, Yang L, Hayes RB, Ahn J. Sex, body mass index, and dietary fiber intake influence the human gut microbiome. PLoS One. 2015;10(4):e0124599. PubMed PMID: 25874569. Pubmed Central PMCID: PMC4398427. doi: 10.1371/journal.pone.0124599

132. Haro C, Rangel-Zuniga OA, Alcala-Diaz JF, Gomez-Delgado F, Perez-Martinez P, Delgado-Lista J, Quintana-Navarro GM, Landa BB, Navas-Cortes JA, Tena-Sempere M, Clemente JC, Lopez-Miranda J, Perez-Jimenez F, Camargo A. Intestinal Microbi- 
ota Is Influenced by Gender and Body Mass Index. PLoS One. 2016;11(5):e0154090. PubMed PMID: 27228093. Pubmed Central PMCID: PMC4881937. doi: 10.1371/ journal.pone. 0154090

133. Mueller S, Saunier K, Hanisch C, Norin E, Alm L, Midtvedt T, Cresci A, Silvi S, Orpianesi C, Verdenelli MC, Clavel T, Koebnick C, Zunft HJ, Dore J, Blaut M. Differences in fecal microbiota in different European study populations in relation to age, gender, and country: a cross-sectional study. Appl Environ Microbiol. 2006;72(2):1027-33. PubMed PMID: 16461645. Pubmed Central PMCID: PMC1392899. doi: 10.1128/ AEM.72.2.1027-1033.2006

134. Katlama C, Deeks SG, Autran B, Martinez-Picado J, van Lunzen J, Rouzioux C, Miller M, Vella S, Schmitz JE, Ahlers J, Richman DD, Sekaly RP. Barriers to a cure for HIV: new ways to target and eradicate HIV-1 reservoirs. Lancet. 2013;381(9883):2109-17. PubMed PMID: 23541541. Pubmed Central PMCID: PMC3815451. doi: 10.1016/ S0140-6736(13)60104-X

135. Margolis DM, Garcia JV, Hazuda DJ, Haynes BF. Latency reversal and viral clearance to cure HIV-1. Science. 2016;353(6297):aaf6517. PubMed PMID: 27463679. Pubmed Central PMCID: PMC5021637. doi: 10.1126/science.aaf6517

136. Siliciano JD, Siliciano RF. Recent developments in the effort to cure HIV infection: going beyond $\mathrm{N}=1$. J Clin Invest. 2016;126(2):409-14. PubMed PMID: 26829622. Pubmed Central PMCID: PMC4731192. doi: 10.1172/JCI86047

137. Allers K, Hutter G, Hofmann J, Loddenkemper C, Rieger K, Thiel E, Schneider T. Evidence for the cure of HIV infection by CCR5Delta32/Delta32 stem cell transplantation. Blood. 2011;117(10):2791-9. PubMed PMID: 21148083. doi: 10.1182/ blood-2010-09-309591

138. Hutter G, Nowak D, Mossner M, Ganepola S, Mussig A, Allers K, Schneider T, Hofmann J, Kucherer C, Blau O, Blau IW, Hofmann WK, Thiel E. Long-term control of HIV by CCR5 Delta32/Delta32 stem-cell transplantation. N Engl J Med. 2009;360(7):692-8. PubMed PMID: 19213682. doi: 10.1056/NEJMoa0802905

139. Henrich TJ, Hanhauser E, Marty FM, Sirignano MN, Keating S, Lee TH, Robles YP, Davis BT, Li JZ, Heisey A, Hill AL, Busch MP, Armand P, Soiffer RJ, Altfeld M, Kuritzkes DR. Antiretroviral-free HIV-1 remission and viral rebound after allogeneic stem cell transplantation: report of 2 cases. Ann Intern Med. 2014;161(5):319-27. PubMed PMID: 25047577. Pubmed Central PMCID: PMC4236912. doi: 10.7326/M14-1027

140. Henrich TJ, Hu Z, Li JZ, Sciaranghella G, Busch MP, Keating SM, Gallien S, Lin NH, Giguel FF, Lavoie L, Ho VT, Armand P, Soiffer RJ, Sagar M, Lacasce AS, Kuritzkes DR. Long-term reduction in peripheral blood HIV type 1 reservoirs following reduced-intensity conditioning allogeneic stem cell transplantation. J Infect Dis. 2013;207(11):1694-702. PubMed PMID: 23460751. Pubmed Central PMCID: PMC3636784. doi: 10.1093/infdis/jit086

141. Luzuriaga K, Gay H, Ziemniak C, Sanborn KB, Somasundaran M, Rainwater-Lovett K, Mellors JW, Rosenbloom D, Persaud D. Viremic relapse after HIV-1 remission in a perinatally infected child. N Engl J Med. 2015;372(8):786-8. PubMed PMID: 25693029. Pubmed Central PMCID: PMC4440331. doi: 10.1056/NEJMc1413931 
142. Persaud D, Gay H, Ziemniak C, Chen YH, Piatak M, Jr., Chun TW, Strain M, Richman D, Luzuriaga K. Absence of detectable HIV-1 viremia after treatment cessation in an infant. N Engl J Med. 2013;369(19):1828-35. PubMed PMID: 24152233. Pubmed Central PMCID: PMC3954754. doi: 10.1056/NEJMoa1302976

143. Saez-Cirion A, Bacchus C, Hocqueloux L, Avettand-Fenoel V, Girault I, Lecuroux C, Potard V, Versmisse P, Melard A, Prazuck T, Descours B, Guergnon J, Viard JP, Boufassa F, Lambotte O, Goujard C, Meyer L, Costagliola D, Venet A, Pancino G, Autran B, Rouzioux C, Group AVS. Post-treatment HIV-1 controllers with a long-term virological remission after the interruption of early initiated antiretroviral therapy ANRS VISCONTI Study. PLoS Pathog. 2013;9(3):e1003211. PubMed PMID: 23516360. Pubmed Central PMCID: PMC3597518. doi: 10.1371/journal.ppat.1003211

144. Goujard C, Girault I, Rouzioux C, Lecuroux C, Deveau C, Chaix ML, Jacomet C, Talamali A, Delfraissy JF, Venet A, Meyer L, Sinet M, Group ACPS. HIV-1 control after transient antiretroviral treatment initiated in primary infection: role of patient characteristics and effect of therapy. Antivir Ther. 2012;17(6):1001-9. PubMed PMID: 22865544. doi: 10.3851/IMP2273

145. Johnston RE, Heitzeg MM. Sex, age, race and intervention type in clinical studies of HIV cure: a systematic review. AIDS Res Hum Retroviruses. 2015;31(1):8597. PubMed PMID: 25313793. Pubmed Central PMCID: 4287187. doi: 10.1089/ AID.2014.0205

146. Hill AL, Rosenbloom DI, Fu F, Nowak MA, Siliciano RF. Predicting the outcomes of treatment to eradicate the latent reservoir for HIV-1. Proc Natl Acad Sci U S A. 2014;111(37):13475-80. PubMed PMID: 25097264. Pubmed Central PMCID: PMC4169952. doi: 10.1073/pnas.1406663111

147. Williams JP, Hurst J, Stohr W, Robinson N, Brown H, Fisher M, Kinloch S, Cooper D, Schechter M, Tambussi G, Fidler S, Carrington M, Babiker A, Weber J, Koelsch KK, Kelleher AD, Phillips RE, Frater J, Investigators SP. HIV-1 DNA predicts disease progression and post-treatment virological control. Elife. 2014;3:e03821. PubMed PMID: 25217531. Pubmed Central PMCID: PMC4199415. doi: 10.7554/eLife.03821

148. Rouzioux C, Hubert JB, Burgard M, Deveau C, Goujard C, Bary M, Sereni D, Viard JP, Delfraissy JF, Meyer L, Group SCS. Early levels of HIV-1 DNA in peripheral blood mononuclear cells are predictive of disease progression independently of HIV-1 RNA levels and CD4+ T cell counts. J Infect Dis. 2005;192(1):46-55. PubMed PMID: 15942893. doi: $10.1086 / 430610$

149. Ananworanich J, Chomont N, Eller LA, Kroon E, Tovanabutra S, Bose M, Nau M, Fletcher JL, Tipsuk S, Vandergeeten C, O’Connell RJ, Pinyakorn S, Michael N, Phanuphak N, Robb ML, Rv, groups RSs. HIV DNA Set Point is Rapidly Established in Acute HIV Infection and Dramatically Reduced by Early ART. EBioMedicine. 2016;11:68-72. PubMed PMID: 27460436. Pubmed Central PMCID: PMC5049918. doi: 10.1016/j.ebiom.2016.07.024

150. Ho YC, Shan L, Hosmane NN, Wang J, Laskey SB, Rosenbloom DI, Lai J, Blankson JN, Siliciano JD, Siliciano RF. Replication-competent noninduced proviruses in the latent reservoir increase barrier to HIV-1 cure. Cell. 2013;155(3):540-51. PubMed PMID: 24243014. Pubmed Central PMCID: 3896327. doi: 10.1016/j.cell.2013.09.020 
151. Bruner KM, Murray AJ, Pollack RA, Soliman MG, Laskey SB, Capoferri AA, Lai J, Strain MC, Lada SM, Hoh R, Ho YC, Richman DD, Deeks SG, Siliciano JD, Siliciano RF. Defective proviruses rapidly accumulate during acute HIV-1 infection. Nat Med. 2016;22(9):1043-9. PubMed PMID: 27500724. Pubmed Central PMCID: PMC5014606. doi: 10.1038/nm.4156

152. Imamichi H, Dewar RL, Adelsberger JW, Rehm CA, O’Doherty U, Paxinos EE, Fauci AS, Lane HC. Defective HIV-1 proviruses produce novel protein-coding RNA species in HIV-infected patients on combination antiretroviral therapy. Proc Natl Acad Sci U S A. 2016;113(31):8783-8. PubMed PMID: 27432972. Pubmed Central PMCID: PMC4978246. doi: 10.1073/pnas.1609057113

153. Eriksson S, Graf EH, Dahl V, Strain MC, Yukl SA, Lysenko ES, Bosch RJ, Lai J, Chioma S, Emad F, Abdel-Mohsen M, Hoh R, Hecht F, Hunt P, Somsouk M, Wong J, Johnston R, Siliciano RF, Richman DD, O’Doherty U, Palmer S, Deeks SG, Siliciano JD. Comparative analysis of measures of viral reservoirs in HIV-1 eradication studies. PLoS Pathog. 2013;9(2):e1003174. PubMed PMID: 23459007. Pubmed Central PMCID: PMC3573107. doi: 10.1371/journal.ppat.1003174

154. Fourati S, Flandre P, Calin R, Carcelain G, Soulie C, Lambert-Niclot S, Maiga A, Ait-Arkoub Z, Tubiana R, Valantin MA, Autran B, Katlama C, Calvez V, Marcelin AG. Factors associated with a low HIV reservoir in patients with prolonged suppressive antiretroviral therapy. J Antimicrob Chemother. 2014;69(3):753-6. PubMed PMID: 24187041. doi: 10.1093/jac/dkt428

155. Cuzin L, Pugliese P, Saune K, Allavena C, Ghosn J, Cottalorda J, Rodallec A, Chaix ML, Fafi-Kremer S, Soulie C, Ouka M, Charpentier C, Bocket L, Mirand A, Guiguet M, Dat Asg. Levels of intracellular HIV-DNA in patients with suppressive antiretroviral therapy. AIDS. 2015;29(13):1665-71. PubMed PMID: 26372277. doi: 10.1097/ QAD.0000000000000723

156. Scully Eileen P. GM, Johnston R, Gorelick R, Lifson JD, Lewin SR, Karn, J Chomont N, Bacchetti P, Deeks SG. Abstract 281: Sex-Based Differences in HIV Reservoir Activity and Residual Immune Activation. CROI, Seattle, Washington2017.

157. Pasternak AO, Lukashov VV, Berkhout B. Cell-associated HIV RNA: a dynamic biomarker of viral persistence. Retrovirology. 2013;10:41. PubMed PMID: 23587031. Pubmed Central PMCID: PMC3637491. doi: 10.1186/1742-4690-10-41

158. Li JZ, Etemad B, Ahmed H, Aga E, Bosch RJ, Mellors JW, Kuritzkes DR, Lederman MM, Para M, Gandhi RT. The size of the expressed HIV reservoir predicts timing of viral rebound after treatment interruption. AIDS. 2016;30(3):343-53. PubMed PMID: 26588174. Pubmed Central PMCID: PMC4840470. doi: 10.1097/ QAD.0000000000000953

159. Katagiri D, Hayashi H, Victoriano AF, Okamoto T, Onozaki K. Estrogen stimulates transcription of human immunodeficiency virus type 1 (HIV-1). Int Immunopharmacol. 2006;6(2):170-81. PubMed PMID: 16399621. doi: 10.1016/j.intimp.2005.07.017

160. Szotek EL, Narasipura SD, Al-Harthi L. 17beta-Estradiol inhibits HIV-1 by inducing a complex formation between beta-catenin and estrogen receptor alpha on the HIV 
promoter to suppress HIV transcription. Virology. 2013;443(2):375-83. PubMed PMID: 23769242. Pubmed Central PMCID: PMC3722310. doi: 10.1016/j.virol.2013.05.027

161. Asin SN, Heimberg AM, Eszterhas SK, Rollenhagen C, Howell AL. Estradiol and progesterone regulate HIV type 1 replication in peripheral blood cells. AIDS Res Hum Retroviruses. 2008;24(5):701-16. PubMed PMID: 18462082. doi: 10.1089/aid.2007.0108

162. Das B, Dobrowolski C, Luttge B, Valadkhan S, Chomont N, Johnston R, Bacchetti P, Hoh R, Gandhi M, Deeks S, Scully E, Karn J. Estrogen Receptor a (ESR1) is a key regulator of HIV-1 latency that imparts gender-specific restrictions on the latent reservoir. PNAS. 2018, in press.

163. Mbonye U, Karn J. Transcriptional control of HIV latency: cellular signaling pathways, epigenetics, happenstance and the hope for a cure. Virology. 2014;454-455:328-39. PubMed PMID: 24565118. Pubmed Central PMCID: 4010583. doi: 10.1016/j.virol.2014.02.008

164. Archin NM, Sung JM, Garrido C, Soriano-Sarabia N, Margolis DM. Eradicating HIV-1 infection: seeking to clear a persistent pathogen. Nat Rev Microbiol. 2014;12(11):75064. PubMed PMID: 25402363. Pubmed Central PMCID: 4383747. doi: 10.1038/nrmicro3352

165. Mamrut S, Avidan N, Staun-Ram E, Ginzburg E, Truffault F, Berrih-Aknin S, Miller A. Integrative analysis of methylome and transcriptome in human blood identifies extensive sex- and immune cell-specific differentially methylated regions. Epigenetics. 2015;10(10):943-57. PubMed PMID: 26291385. Pubmed Central PMCID: PMC4844205. doi: 10.1080/15592294.2015.1084462

166. Nosrati A, Tsai KK, Goldinger SM, Tumeh P, Grimes B, Loo K, Algazi AP, Nguyen-Kim TDL, Levesque M, Dummer R, Hamid O, Daud A. Evaluation of clinicopathological factors in PD-1 response: derivation and validation of a prediction scale for response to PD-1 monotherapy. Br J Cancer. 2017;116(9):1141-7. PubMed PMID: 28324889. Pubmed Central PMCID: PMC5418446. doi: 10.1038/bjc.2017.70

167. National Institutes of Health. NIH Grants Policy Statement 2017. Available from: https://grants.nih.gov/policy/nihgps/index.htm

168. Committee on E. ACOG Committee Opinion No. 646: Ethical Considerations for Including Women as Research Participants. Obstet Gynecol. 2015;126(5):e100-7. PubMed PMID: 26488521. doi: 10.1097/AOG.0000000000001150. Available from: https:// www.acog.org/-/media/Committee-Opinions/Committee-on-Ethics/co646.pdf?d$\mathrm{mc}=1 \& \mathrm{ts}=20180601 \mathrm{~T} 1400014828$

169. (NIAID) National Institute of Allergy and Infectious Diseases. Selective Estrogen Receptor Modulators to Enhance the Efficacy of Viral Reactivation With Histone Deacetylase Inhibitors 2018. Available from: https://clinicaltrials.gov/ct2/show/NCT03382834 


\section{FOOTNOTES}

Submitted April, 2018 | Accepted June 7, 2018 | Published July 13, 2018

\section{COPYRIGHT}

(C) Pathogens and Immunity 2018

This work is licensed under a Creative Commons Attribution 4.0 International License. To view a copy of this license, visit http://creativecommons.org/licenses/by/4.0/ 